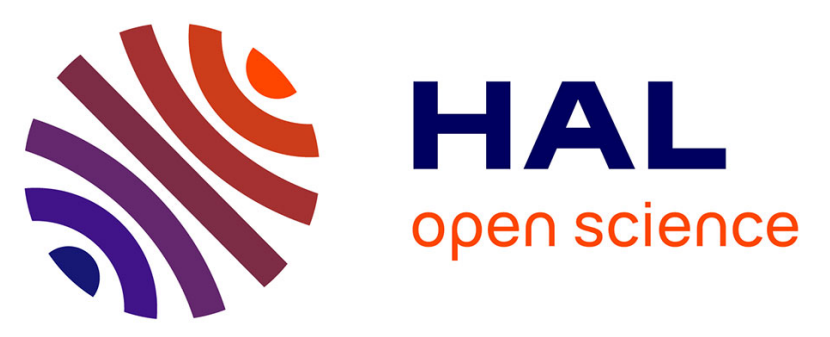

\title{
Tectono-sedimentary evolution of a rift system controlled by Permian post-orogenic extension and metamorphic core complex formation (Bidarray Basin and Ursuya dome, Western Pyrenees)
}

Nicolas Saspiturry, Bryan Cochelin, Philippe Razin, Sophie Leleu, Baptiste Lemirre, Chloé Bouscary, Benoît Issautier, Olivier Serrano, Eric Lasseur, Thierry Baudin, et al.

\section{- To cite this version:}

Nicolas Saspiturry, Bryan Cochelin, Philippe Razin, Sophie Leleu, Baptiste Lemirre, et al.. Tectonosedimentary evolution of a rift system controlled by Permian post-orogenic extension and metamorphic core complex formation (Bidarray Basin and Ursuya dome, Western Pyrenees). Tectonophysics, 2019, 768, pp.228180. 10.1016/j.tecto.2019.228180 . insu-02269899

\section{HAL Id: insu-02269899}

https://hal-insu.archives-ouvertes.fr/insu-02269899

Submitted on 23 Aug 2019

HAL is a multi-disciplinary open access archive for the deposit and dissemination of scientific research documents, whether they are published or not. The documents may come from teaching and research institutions in France or abroad, or from public or private research centers.
L'archive ouverte pluridisciplinaire HAL, est destinée au dépôt et à la diffusion de documents scientifiques de niveau recherche, publiés ou non, émanant des établissements d'enseignement et de recherche français ou étrangers, des laboratoires publics ou privés.

\section{(1) $(1) \Theta$}

Distributed under a Creative Commons Attribution - NonCommercial - NoDerivatives 44.0 


\section{Journal Pre-proof}

Tectono-sedimentary evolution of a rift system controlled by

Permian post-orogenic extension and metamorphic core complex formation (Bidarray Basin and Ursuya dome, Western Pyrenees)

Nicolas Saspiturry, Bryan Cochelin, Philippe Razin, Sophie Leleu, Baptiste Lemirre, Chloé Bouscary, Benoit Issautier, Olivier Serrano, Eric Lasseur, Thierry Baudin, Cécile Allanic

PII: S0040-1951(19)30287-2

DOI: https://doi.org/10.1016/j.tecto.2019.228180

Reference: TECTO 228180

To appear in: Tectonophysics

Received date: 27 November 2018

Revised date: 14 August 2019

Accepted date: 19 August 2019

Please cite this article as: N. Saspiturry, B. Cochelin, P. Razin, et al., Tectono-sedimentary evolution of a rift system controlled by Permian post-orogenic extension and metamorphic core complex formation (Bidarray Basin and Ursuya dome, Western Pyrenees), Tectonophysics(2018), https://doi.org/10.1016/j.tecto.2019.228180

This is a PDF file of an article that has undergone enhancements after acceptance, such as the addition of a cover page and metadata, and formatting for readability, but it is not yet the definitive version of record. This version will undergo additional copyediting, typesetting and review before it is published in its final form, but we are providing this version to give early visibility of the article. Please note that, during the production process, errors may be discovered which could affect the content, and all legal disclaimers that apply to the journal pertain.

C 2018 Published by Elsevier. 


\section{Tectono-sedimentary evolution of a rift system controlled by Permian post- orogenic extension and metamorphic core complex formation (Bidarray Basin and Ursuya dome, Western Pyrenees)}

Nicolas Saspiturry $^{\mathrm{a}^{*}}$, Bryan Cochelin $^{\mathrm{b}}$, Philippe Razin ${ }^{\mathrm{a}}$, Sophie Leleu $^{\mathrm{a}}$, Baptiste Lemirre ${ }^{\mathrm{c}}$, Chloé Bouscary $^{\mathrm{a}}$, Benoit Issautier ${ }^{\mathrm{d}}$, Olivier Serrano ${ }^{\mathrm{d}}$, Eric Lasseur ${ }^{\mathrm{d}}$, Thierry Baudin ${ }^{\mathrm{d}}$, Cécile Allanic $^{\mathrm{d}}$

${ }^{a}$ Université Bordeaux Montaigne / EA 4592 Géoressources \& Environnement, 1 allée Fernand Daguin33607 Pessac cedex, France

${ }^{\text {b } U n i v e r s i t e ́ ~ d ' O r l e ́ a n s, ~ C N R S, ~ B R G M, ~ I S T O, ~ U M R ~ 7327, ~ 1 A ~ R u e ~ d e ~ l a ~ F e r o l l e r i e, ~} 45071$ Orléans, France

${ }^{\mathrm{c}}$ Géosciences Environnement Toulouse, Université de Toulouse, CNRS, IRD, UPS, CNES, 31400 Toulouse, France

${ }^{\mathrm{d}}$ Bureau de Recherche Géologique et Minière, 3 Avenue Claude Guillemin, 45100 Orléans, France *Corresponding author (e-mail: saspiturry.nicolas@gmail.com)

\section{ABSTRACT}

This study documents the sedimentary and structural response of continental crust in relatively hot lithosphere that is subjected to extension. We focus on the Permian rift system in the Western Pyrenees, where the narrow, post-orogenic intracontinental extensional Bidarray Basin is in contact with late Variscan granulites of the Ursuya massif. The western margin of the N-S trending Bidarray Basin preserves alluvial fans dominated by hyperconcentrated flows and interdigitating eastward into a N-S trending fluvial system. Structural analysis of the Ursuya granulites shows that they underwent orogen-parallel midcrustal flow and were exhumed owing to strain localization during retrogressive metamorphism within an extensional shear zone flanking an E-W elongated domal structure. We show that the Bidarray Basin formed during Permian time on the hanging wall of a southvergent detachment system that developed in response to the formation of an immature "atype" metamorphic core complex (the Ursuya massif) under regional E-W extension, resulting in homogeneous thinning of the hot crust. This core complex was later exposed by denudation during Cenomanian time. The preservation of the Permian and Triassic paleogeography and 
structure indicates that there has been no lateral motion between Iberia and Europe in the study area. The Cretaceous Pamplona transfer zone, responsible for the shift of the Mesozoic rift axis, reactivated a N-S trending Permian crustal heterogeneity.

Keywords: Post-orogenic rift, Permian, Metamorphic core complex, Detachment, Granulites, Continental deposits

\section{Introduction}

The structural architecture of crust subjected to extension depends strongly on the rheological structure of the lithosphere. The temperature at the Moho controls how deformation is accommodated in the crust (see the critical review of Brun et al., 2017). Whereas a cold lithosphere tends toward localized deformation, leading to necking of the whole crust, a hot lithosphere undergoes distributed deformation and necking confined to the upper crust, which leads to the formation of metamorphic core complexes (MCCs) (Brun, 1999; Tirel et al., 2004, 2008; Gueydan et al., 2008). Exhumation of the ductile crust within MCCs is favored by activation of extensional detachment faults (Coney, 1980). In response to increasing extension and uplift of the detachment footwall, half-grabens or graben basins are created and filled progressively by proximal sediments. This crustal configuration was first defined in the Basin and Range province (Davis and Coney, 1979; Wernicke, 1981; Wernicke and Burchfiel, 1982; Wernicke, 1985; Davis et al., 1986; Lister and Davis, 1989; Malavielle, 1993) and later in the Aegean domain (Lister et al., 1984; Avigad and Garfunkel, 1989). The two most common types of MCCs described in the Aegean domain are defined by the trend of the foliation dome with respect to the direction of regional crustal stretching: "a-type" MCCs are elongated parallel and "b-type" MCCs are elongated normal to the stretching direction (Jolivet et al., 2004, Le Pourhiet et al., 2012). Specifically, the main detachment faults flanking these two MCC types are either roughly parallel to or perpendicular to the direction 
of stretching. MCCs have been described in many tectonic settings, including areas of backarc extension, lateral escape into orogenic plateaus, late-orogenic collapse or anorogenic extension (see the review by Jolivet and Goffé, 2000). It has been demonstrated that the late evolution of the Variscan belt in Western Europe was a favorable context for the development of MCCs, as (1) the overthickened hinterland was affected by gravitational collapse (Echtler and Malavieille, 1990; Malavieille et al., 1990; Burg et al., 1994; Roger et al., 2015) and (2) late- and post-orogenic delamination of the lithospheric mantle led to widespread magmatism and high temperature-low pressure (HT-LP) metamorphism (including production of granulites) in the foreland during the Carboniferous-Permian transition (e.g., Pin and Vielzeuf, 1983; Denèle et al., 2014; Martínez-Catalán et al., 2014; Laurent et al., 2017). Furthermore, crustal extension affected Western Europe during the Permian, leading to the formation of numerous sedimentary basins, as in the Pyrenees (Lucas, 1985; Bixel and Lucas, 1987). Unlike the Massif Central (e.g., Echtler and Malavieille, 1990; Brun and Van den Driessche, 1994; Pochat and Van den Driessche, 2011), the relationship between basin formation and exhumation of Early Permian migmatites or granulites has not been investigated in the Pyrenees; rather, the major studies have focused on the sedimentary environment of the Permian and Triassic deposits and the associated alkaline volcanism (Bixel and Lucas, 1983; Lucas, 1985; Lago et al., 2004; Rodriguez-Mendez et al., 2014; Gretter et al., 2015; Lloret et al., 2018). Furthermore, the Alpine overprint in these Permian basins due to nappe stacking during Pyrenean mountain building makes it difficult to reconstruct the tectonic context of basin formation (e.g., Saura and Teixell, 2006; IzquierdoLlavall et al., 2013, 2014).

The Bidarray Basin, a Permian basin in the Western Pyrenees (Fig. 1), was only slightly deformed during the subsequent Pyrenean orogeny and is therefore a very favorable place to study the evolution of extensive post-orogenic basins. Moreover, it is located 
immediately south of the late-Variscan granulites forming the Ursuya massif (Fig. 2), making it a key place to investigate the structural response of both upper and lower crust to regional post-orogenic extension. In this work, we present a sedimentary analysis of the Bidarray Basin and a structural analysis of both the basin and the adjacent Ursuya granulitic dome. The geologic maps presented here derive from the harmonization and updating of the 1:50,000 maps published by the geological agencies of France and Spain (Casteras, 1971; Adler et al., 1972; Juch et al., 1972; Boissonnas et al., 1974; Le Pochat et al., 1976, 1978). We propose a tectonic model of crustal extension that accounts for both the development of the Bidarray Basin and the exhumation of granulites within an MCC in Permian time. We also discuss the role of this Permian domain in the subsequent deformation phases, such as Cretaceous rifting and the Pyrenean orogeny.

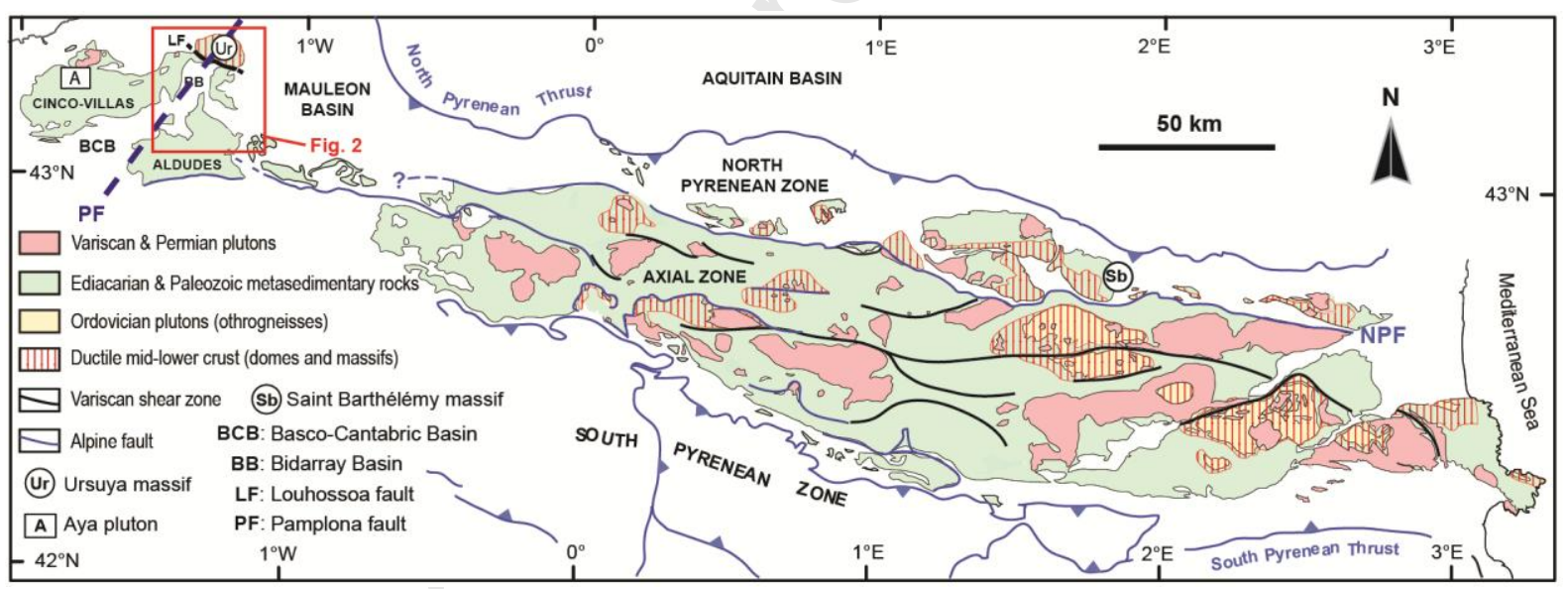

Fig. 1. Sketch map of the Pyrenees showing its major structural domains: North Pyrenean Zone, Axial Zone and South Pyrenean Zone. The Bidarray Basin, in the western Pyrenees, is separated from the Ursuya granulitic dome by the Louhossoa fault and is bisected by the Pamplona fault, which separates the Mauléon and Basco-Cantabric basins of Early Cretaceous age (modified from Cochelin et al., 2017). 


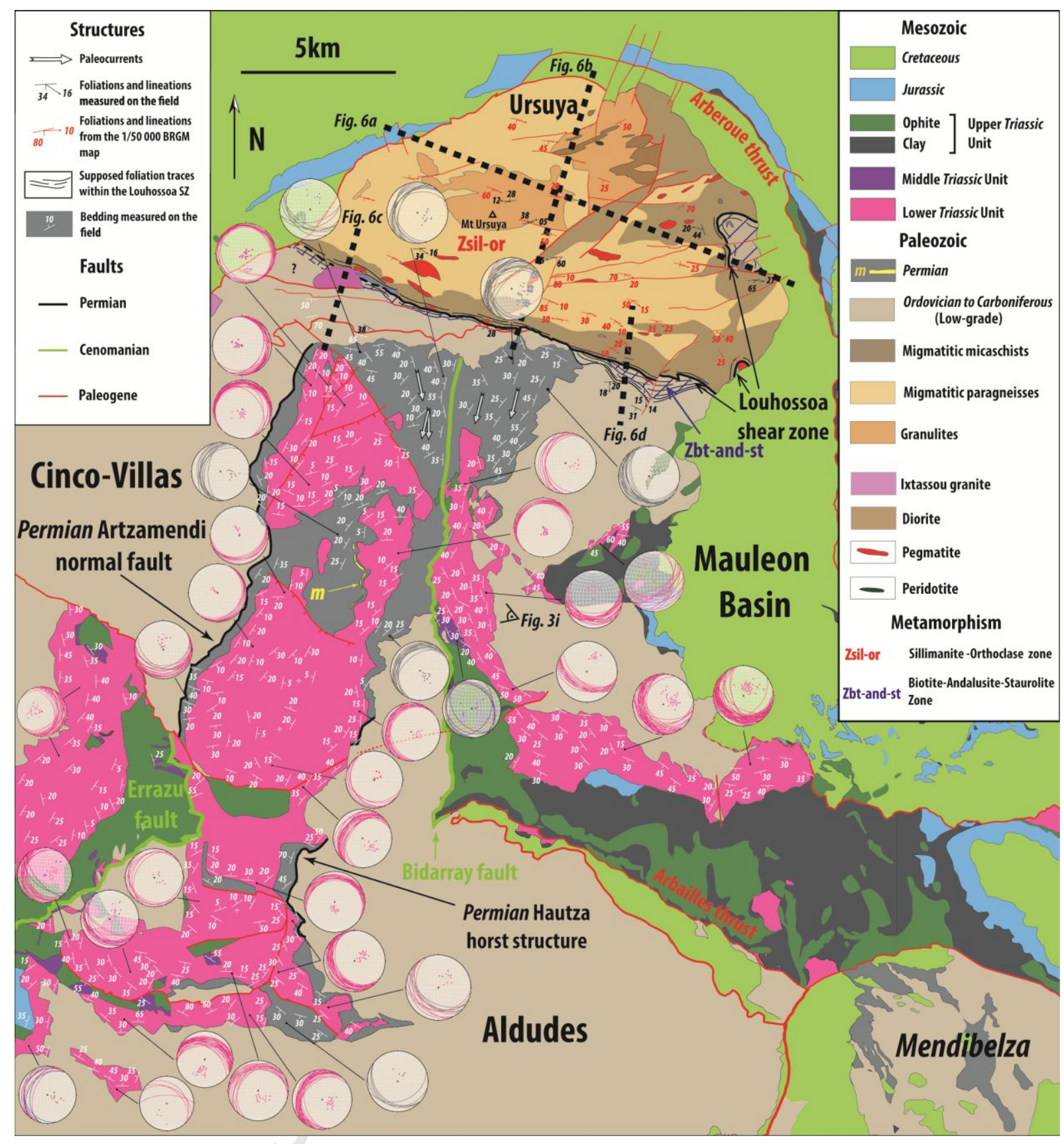

Fig. 2. Simplified geologic map of the Bidarray Basin. This Permian basin lies between the Aldudes, Cinco-Villas and Ursuya massifs of Paleozoic age. The Bidarray Basin includes the Permian and Triassic rocks southwest of the Mauléon rift basin of Albian-Cenomanian age and south of the Louhossoa shear zone (modified from Casteras, 1971; Adler et al., 1972; Juch et al., 1972; Boissonnas et al., 1974; Le Pochat et al., 1976, 1978). Black lines: Permian Faults; green lines: Cenomanian Faults, red lines: Paleogene Faults. The white strike and dip 
symbols as well as the stereoplots represent new measurements of bedding planes. The gray, pink, purple and blue lines on the stereoplots represent bedding plane measurements respectively in Permian deposits, Late Triassic sandstones, Muschelkalk limestones and Jurassic limestones. The biotite-andalusite-staurolite metamorphic facies (Zbt-and-st) is indicated by blue hachures, and the bulk of the Ursuya unit consists of the sillimaniteorthoclase facies (Zsil-or). Late Permian alkaline magmatism is signified by a yellow field labeled "m".

\section{Geologic setting}

\subsection{The Pyrenean Variscan belt}

The Variscan belt of Western Europe records convergence and collisional mountain building between the Laurussia paleocontinent and the northern margin of Gondwana during the Devonian and Carboniferous (e.g., Matte and Hirn, 1988; Franke, 1989; Matte, 2001; Ballèvre et al., 2009; Paquette et al., 2017; Lotout et al., 2018). The Variscan belt was affected from 360 to 290 Ma by partial melting, post-orogenic extension (e.g., Faure et al., 2009) and the development of major transcurrent faults (Arthaud and Matte, 1975; Burg et al., 1994). In this orogenic context, the Pyrenees were located in the foreland of the Variscan belt and were mainly affected by late Variscan HT-LP metamorphism due to lithospheric mantle delamination (Denèle et al., 2014; Cochelin et al., 2017; Lemirre et al., 2019 and references therein). This metamorphism occurred between 310 and 290 Ma (see Denèle et al., 2014; Lemirre et al., 2019; Poitrenaud et al., 2019) and was responsible for partial melting of the middle and lower crust, which then intruded into the base of the upper crust of the Axial Zone as gneiss domes in compressional settings (Fig. 1; Denèle et al., 2007; 2009; Cochelin et al., 2017, 2018a, 2018b). Formed in an overall context of N-S horizontal shortening, these domes are elongated parallel to the regional direction of stretching in the middle and lower crust, like 
“a-type” MCCs (Cochelin et al., 2017, 2018b). Deposition of the earliest thin volcaniclastic sediments occurred in the Pyrenees synchronously with ductile flow within these gneiss domes (e.g., compare the ages obtained by Pereira et al., 2014, and Lemirre et al., 2019). While the partially exhumed middle crustal rocks correspond to migmatites in the Axial Zone, those exhumed in the North Pyrenean Zone and the Basque massifs in the westernmost Pyrenees (Fig. 1) reached the granulite facies and were mainly affected by intense crustal thinning during extension at the Carboniferous-Permian transition (de Saint-Blanquat et al., 1990; de Saint-Blanquat, 1993; Olivier et al., 2004; Lemirre, 2018).

\subsection{Post-Variscan Permian-Triassic extensional basins}

It has long been accepted that the Permian extensional phase represents the transition between the Variscan orogenic cycle and the rifting that led to the breakup of Pangea and the opening of the Neo-Tethys ocean (e.g., Sengör et al., 1984; Stampfli, 2012). The Permian sediments were erosional products of the Paleozoic substratum, deposited mainly by different fluvial systems and alluvial fans in intracontinental basins (Lucas, 1968, 1977, 1985; Cassinis et al., 1995). The Pyrenees are characterized by a continuous record of Carboniferous to Permian sedimentation, like that in the Massif Central (e.g., Pellenard et al., 2017) but with far fewer lacustrine deposits (e.g., Pochat and Van den Driessche, 2011). The rocks are generally redbeds and do not record any flora or fauna. The Permian deposits are in unconformable or fault contact with the folded Variscan substratum. Despite the lack of geochronological constraints within the Bidarray Basin, a middle to late Permian age can be advocated for these deposits because of (1) the alkaline magmatism interbedded with sediments and developing in the basin axis (Adler et al., 1972) that is known to be of latest Permian age elsewhere in the Pyrenees (Bixel and Lucas, 1983, 1987; Lucas, 1985; Orejana et al., 2008; Pereira et al., 2014), (2) the absence at the base of the sequence of the gray 
lacustrine deposits of latest Carboniferous (Stephanian) to early Permian age identified in the Ossau basin (Bixel, 1984; Lucas, 1985) and in the central Pyrenees (e.g., Gretter et al., 2015; Lloret et al., 2018) (although redbeds of that age are not ruled out in the Bidarray Basin), and (3) the presence of the regional unconformity between uppermost Permian and overlying Triassic deposits that is known throughout the Pyrenees (Mey et al., 1968; Nagtegaal, 1969; Gisbert, 1981; Lucas, 1985; Gretter et al., 2015 and references therein).

Post-Variscan extensional basins are characterized in the Pyrenees by a half-graben morphology (Bixel and Lucas, 1987; Gretter et al., 2015; Lloret et al., 2018). The role of tectonic activity during sedimentation of breccia deposits in these basins has long been recognized (Lucas, 1977, 1985). The Alpine orogeny strongly affected the Permian basins bordering the Axial Zone of the Pyrenees and reactivated most of the Permian extensional and transtensional faults (e.g., Saura and Teixell, 2006; Izquierdo-Llavall et al., 2013, 2014). This Alpine overprint appears to decrease to the west, especially in the Basque massifs where the amount of shortening was less than in the Central and Eastern Pyrenees (Teixell, 1998). The Bidarray and Haut-Béarn basins are the most prominent preserved Permian depocenters of the Western Pyrenees (Bixel, 1984; Lucas, 1985). Two sets of structural features appear to have affected the development of the Permian-Triassic basins in this area, NNE-SSW trending faults that controlled the development of the Permian basins and ENE-WSW trending structures that were active during the Late Triassic (Lucas, 1985). These have been linked to a larger scale E-W sinistral fault system (Arthaud and Matte, 1975; Souquet et al., 1977; Lucas, 1985). Triassic deposits in these basins unconformably overlie both the Permian deposits and the Variscan sedimentary substratum (Lucas et al., 1980; Curnelle, 1983; Durand, 2006). Lucas (1968) and Curnelle (1983) defined the Permian-Triassic boundary in the Pyrenees as the base of the Upper Triassic (Carnian) monogenic conglomerates (Lucas et al., 1980). These coarse facies are therefore probably comparable to deposits related to the early (Triassic) 
phase of Atlantic rifting (Leleu et al., 2016). The Late Triassic extensional phase was then recorded by the development of thick evaporite deposits (Curnelle, 1983) and mantle-derived intrusions (ophites; see Rossi et al., 2003, and Fig. 2).

\subsection{Present-day structure of the Western Pyrenees}

The Pyrenean mountain range results from N-S shortening due to convergence and collision between Iberia and Europe from late Santonian to early Miocene time (Puigdefàbregas and Souquet, 1986; Olivet, 1996). The Pyrenees are classically divided into three structural zones: the Axial Zone consisting of a Variscan substratum, the South Pyrenean Zone, and the North Pyrenean Zone (Fig. 1; Choukroune, 1976). In the Western Pyrenees, the North Pyrenean Zone is represented by the Cretaceous Mauléon Basin, thrusted to the north onto the Aquitaine domain and bordered to the south by the Axial Zone. The Mauléon Basin is bounded to the west by Paleozoic crustal blocks known as the Basque massifs (Heddebaut, 1973; Muller and Roger, 1977) and is underlain by mantle rock at depths less than $10 \mathrm{~km}$ (Wang et al., 2016), making it a hyperextended Cretaceous rift basin (Jammes et al., 2009; Lagabrielle et al., 2010; Masini et al., 2014; Tugend et al., 2014; Teixell et al., 2016; Saspiturry et al., 2019). The Bidarray Basin lies between the Mauléon Basin and the Basco-Cantabric Basin, a similar hyperextended rift basin of Cretaceous age (Rat et al., 1983; Quintana et al., 2015; Ducoux, 2017) (Fig. 1). Previous work has shown that segmentation of the Cretaceous rifting in this area was controlled by a N20 structural trend, and in particular by a putative structure called the Pamplona fault (Fig. 1; Schoeffler, 1982; Razin, 1989). The Pamplona fault is assumed to be a lithospheric structure without any expression at the outcrop scale, with the exception of $\mathrm{N} 20^{\circ}$ oriented diapirs south of the Aldudes massif (Richard, 1986). 
The Bidarray Basin corresponds to the upper part of a Paleozoic basement complex known as the Basque massifs, divided here into four units (Fig. 2). The Aldudes and CincoVillas units are massifs composed of Ordovician to Carboniferous sedimentary rocks (Laverdière, 1930; Lamare, 1944; Heddebaut, 1967; Muller and Roger, 1977). The Ursuya unit (Viennot and Kieh, 1928; Lamare, 1939; Vielzeuf, 1984) is a massif mainly composed of Precambrian to Ordovician metasediments (Boissonnas et al., 1974) affected by HT-LP metamorphism that reached granulite facies during the early and middle Permian (Vielzeuf, 1984; Hart et al., 2016; Vacherat et al., 2017; Lemirre, 2018). The boundary between the Ursuya massif and Bidarray Basin is defined by the Louhossoa fault (Lamare, 1931; Heddebaut, 1973; Lucas, 1985).

The metamorphic rocks of the highest grade granulites and surrounding migmatites are located in the center of the Ursuya massif, where they formed an anatectic dome (Boissonnas et al., 1974; Vielzeuf, 1984). The massif is interpreted as a part of the Variscan intermediate crust where metamorphism of the deepest facies took place at around $6 \pm 0.5$ kbar and $775 \pm$ $50^{\circ} \mathrm{C}$ (Vielzeuf, 1984). The U-Pb age dataset obtained by Hart et al. (2016) and Vacherat et al. (2017) from gneisses of the Ursuya massif indicates that granulites and paragneisses crystallized and were deformed between 295 and 274 Ma. The Itxassou pluton intruded the southern part of the metamorphic series during this time, at 276.8 $\pm 1.9 \mathrm{Ma}$ (Vacherat et al., 2017). Such late Permian plutonism is well known in the Basque massifs; for instance, the Aya pluton was emplaced within the Cinco-Villas massif at $267.1 \pm 1.1$ Ma (Denèle et al., 2012). The Ursuya granulitic unit was cooled below $300^{\circ} \mathrm{C}$ at the end of the Triassic, as evidenced by the $200 \mathrm{Ma}$ cooling age obtained by ${ }^{39} \mathrm{Ar} /{ }^{40} \mathrm{Ar}$ dating of paragneisses of the Ursuya massif (Masini et al., 2014). Similar P/T paths indicating partial exhumation of granulites related to extension have been recorded across the Pyrenees (Vielzeuf, 1984; Guitard et al., 1996; de Saint-Blanquat et al., 1990; de Saint-Blanquat, 1993; Olivier et al., 
2004). Nevertheless, the tectonic history that led to the exhumation of the Ursuya granulites remains unconstrained, as does its relationship with the coeval formation of the Bidarray Basin.

\section{Facies association and depositional models}

This section presents results of our sedimentary analysis based on field work in the Bidarray Basin. We characterized 11 Permian and Triassic sedimentary facies from which we defined 5 facies associations, described in detail below, that represent various depositional processes and environments in a continental realm (Fig. 3 and Table 1). The facies associations are named as follows: alluvial fans dominated by hyperconcentrated flows (FA1), debris-flow alluvial fans (FA2), coarse fluvial (FA3a), floodplain (FA3b), and braided fluvial (FA4). The first four associations represent the Permian deposits of the Bidarray Basin, in which we defined two types of alluvial fans (FA1 and FA2). The alluvial fan facies are localized along the western basin margin, and the central part of the basin is dominated by deposits of a longitudinal fluvial system (FA3a) and floodplain deposits (FA3b). The last facies association (FA4) characterizes both the coarse fluvial Triassic deposits that overlie the Permian continental sequence and the surrounding Paleozoic substratum. 

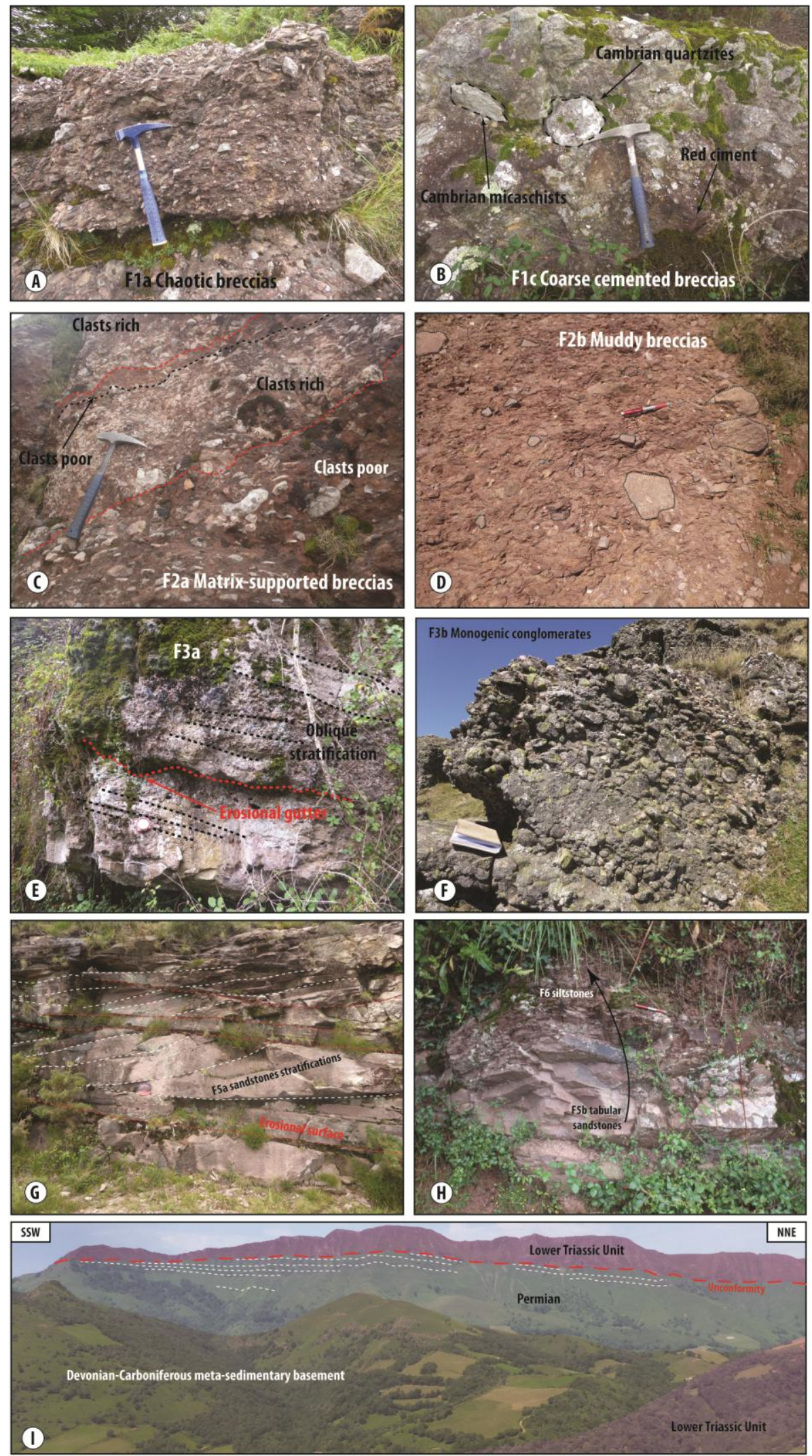

Fig. 3. Outcrop photographs representing Permian-Triassic continental facies of the Bidarray

Basin. (A) F1a facies: chaotic breccia consisting of Paleozoic blocks aligned parallel with 
stratification; the matrix is microbreccia with Paleozoic clasts. (B) F1c facies: cemented poorly sorted breccia with Cambrian clasts ranging from granules to blocks (up to $40 \mathrm{~cm}$ in diameter). (C) F2a facies: matrix-supported breccia with fine-grained matrix and intercalated clast-rich breccia derived from Devonian to Carboniferous basement rocks. (D) F2b facies: muddy breccia consisting of polygenic angular Paleozoic clasts supported by a fine-grained matrix. (E) F3a facies: polygenic conglomerate made of subrounded pebbles (average size 2$3 \mathrm{~cm}$ ); note planar oblique cross-stratification 5-20 $\mathrm{cm}$ thick (black dashed lines) and erosional gutter at its base (red dashed line). (F) F3b facies: monogenic conglomerate containing quartzite pebbles (average size $8 \mathrm{~cm}$ ). (G) F5a facies: coarse amalgamated sandstone with 3D cross-stratification. (H) F5b tabular sandstone grading to F6 siltstone at top. (I) Annotated panoramic view of Iparla peak showing the unconformity between Triassic conglomerates and Permian deposits. The apparent erosional truncation of the Permian deposits toward the SSW is evidence of northward tilting of the Permian deposits before the Triassic conglomerates were laid down. 
Table 1. Lithofacies and depositional environments of Permian and Lower Triassic strata of the Bidarray Basin.

\begin{tabular}{|c|c|c|c|}
\hline Lithofacies & Description & Sedimentary structures & $\begin{array}{l}\text { Depositional } \\
\text { environment }\end{array}$ \\
\hline $\begin{array}{l}\text { F1a. Chaotic } \\
\text { breccia }\end{array}$ & $\begin{array}{l}\text { Matrix with polygenic granules }(1-6 \\
\mathrm{mm}) \\
\text { Units } 2-10 \mathrm{~m} \text { thick } \\
\text { Angular polygenic clasts }(2-30 \mathrm{~cm} \text {; } \\
\text { average size } 8 \mathrm{~cm})\end{array}$ & $\begin{array}{l}\text { Poorly sorted (chaotic fabric) } \\
\text { Clasts aligned with } \\
\text { stratification } \\
\text { Rare cross-stratification } \\
\text { Nonerosive base }\end{array}$ & $\begin{array}{l}\text { Hyperconcentrated } \\
\text { flows in alluvial fans } \\
\text { (Pierson and Scott, } \\
\text { 1985; Benvenuti and } \\
\text { Martini, 2002) }\end{array}$ \\
\hline $\begin{array}{l}\text { F1b. Fine- } \\
\text { grained } \\
\text { breccia }\end{array}$ & $\begin{array}{l}\text { Polygenic clast-supported breccia } \\
\text { Angular to subangular clasts (average } \\
\text { size } 5 \mathrm{~mm} \text {; max } 30 \mathrm{~cm} \text { ) } \\
\text { Red silty matrix } \\
\text { Units } 2-15 \mathrm{~m} \text { thick }\end{array}$ & $\begin{array}{l}\text { Well sorted } \\
\text { Clasts aligned with bedding } \\
\text { Some cross-stratification }\end{array}$ & $\begin{array}{l}\text { Distal } \\
\text { hyperconcentrated } \\
\text { flows in alluvial fans } \\
\text { (Pierson and Scott, } \\
\text { 1985; Benvenuti and } \\
\text { Martini, 2002) }\end{array}$ \\
\hline $\begin{array}{l}\text { F1c. } \\
\text { Cemented } \\
\text { breccia }\end{array}$ & $\begin{array}{l}10 \mathrm{~m}^{2} \text { to } 30 \mathrm{~m}^{2} \text { patches } \\
\text { Cemented matrix of red coarse-grained } \\
\text { sandstone } \\
\text { Polygenic angular clasts ranging from } \\
\text { granules to blocks (max } 40 \mathrm{~cm} \text { ) }\end{array}$ & $\begin{array}{l}\text { Poorly sorted (chaotic fabric) } \\
\text { Absence of bedding }\end{array}$ & $\begin{array}{l}\text { Debris flows in alluvial } \\
\text { fans (Blair and } \\
\text { McPherson, 1994; } \\
\text { Iverson, 1997) }\end{array}$ \\
\hline $\begin{array}{l}\text { F2a. Matrix- } \\
\text { supported } \\
\text { breccia }\end{array}$ & $\begin{array}{l}\text { Polygenic breccia } \\
\text { Muddy matrix } \\
\text { Units } 1-5 \mathrm{~m} \text { thick }\end{array}$ & $\begin{array}{l}\text { Clasts aligned with } \\
\text { stratification } \\
\text { Relatively well sorted clast- } \\
\text { rich beds }\end{array}$ & $\begin{array}{l}\text { Noncohesive debris } \\
\text { flows in alluvial fans } \\
\text { (Blair and McPherson, } \\
\text { 1994; Iverson, 1997) }\end{array}$ \\
\hline $\begin{array}{l}\text { F2b. Muddy } \\
\text { breccia }\end{array}$ & $\begin{array}{l}\text { Matrix-supported breccias } \\
\text { Beds } 30 \mathrm{~cm} \text { to } 2 \mathrm{~m} \text { thick } \\
\text { Polygenic angular clasts (average size } 6 \\
\mathrm{~cm} \text {; } \max 30 \mathrm{~cm} \text { ) }\end{array}$ & $\begin{array}{l}\text { Poorly sorted } \\
\text { Some beds with inverse } \\
\text { coarse tail grading }(2-30 \mathrm{~cm} \\
\text { thick) } \\
\text { Nonerosive base }\end{array}$ & $\begin{array}{l}\text { Cohesive debris flows } \\
\text { in alluvial fans (Blair } \\
\text { and McPherson, 1994; } \\
\text { Iverson, 1997) }\end{array}$ \\
\hline $\begin{array}{l}\text { F3a. } \\
\text { Polygenic } \\
\text { conglomerate }\end{array}$ & $\begin{array}{l}\text { Polygenic conglomerate } \\
\text { Rounded to subrounded cobbles } \\
\text { (average size } 2-3 \mathrm{~cm} \text { ) } \\
\text { Intercalations of tabular medium to } \\
\text { coarse sandstone } \\
\text { Fining-upward sandstone sequences } \\
\text { (30 cm to } 3 \mathrm{~m} \text { thick) }\end{array}$ & $\begin{array}{l}\text { Conglomerate: fairly well } \\
\text { sorted; planar oblique cross- } \\
\text { stratification; erosive base; } \\
\text { erosional gutters } \\
\text { Sandstone: low-angle } \\
\text { bedding; polygenic lag }\end{array}$ & $\begin{array}{l}\text { Bedload deposits of } \\
\text { longitudinal fluvial } \\
\text { system (Rust, 1978; } \\
\text { Bridge, 2009) }\end{array}$ \\
\hline $\begin{array}{l}\text { F3b. } \\
\text { Monogenic } \\
\text { conglomerate }\end{array}$ & $\begin{array}{l}\text { Monogenic conglomerate } \\
\text { Amalgamated fining-upward erosive } \\
\text { beds ( } 1-5 \mathrm{~m} \text { thick) } \\
\text { Matrix of coarse-grained sandstone }\end{array}$ & $\begin{array}{l}\text { Well sorted } \\
\text { Low-angle to oblique cross- } \\
\text { stratification in some bed } \\
\text { tops } \\
\text { Pebbles imbricated }\end{array}$ & $\begin{array}{l}\text { Braided channel } \\
\text { deposits (Miall, 1977a, } \\
\text { 1977b; Bridge, 2009) }\end{array}$ \\
\hline $\begin{array}{l}\text { F4. } \\
\text { Lenticular } \\
\text { stratified } \\
\text { breccia }\end{array}$ & $\begin{array}{l}\text { Polygenic lenticular breccia } \\
\text { Matrix of red fine-grained siltstone } \\
\text { Angular clasts (average size of } 2-5 \mathrm{~cm} \text { ) } \\
\text { Beds } 30 \mathrm{~cm} \text { to } 2 \mathrm{~m} \text { thick }\end{array}$ & $\begin{array}{l}\text { Moderately well sorted } \\
\text { Some oblique cross- } \\
\text { stratification }\end{array}$ & $\begin{array}{l}\text { Channel-fill deposits } \\
\text { preserving the base of } \\
\text { dune cross-strata } \\
\text { (Bridge, 1993, 2009) }\end{array}$ \\
\hline $\begin{array}{l}\text { F5a. Coarse } \\
\text { amalgamated } \\
\text { sandstone }\end{array}$ & $\begin{array}{l}\text { Coarse amalgamated sandstone } \\
\text { Units } 1-10 \mathrm{~m} \text { thick } \\
\text { Fining- and thinning-upward beds (10- } \\
50 \mathrm{~cm} \text { thick) }\end{array}$ & $\begin{array}{l}\text { Well sorted } \\
3 \mathrm{D} \text { cross-stratification }(20 \\
\mathrm{cm} \text { to } 1 \mathrm{~m} \text { thick) }\end{array}$ & $\begin{array}{l}\text { Coarse fluvial braided } \\
\text { channels (Miall, 1977a, } \\
\text { 1977b; Bridge, 2009) }\end{array}$ \\
\hline $\begin{array}{l}\text { F5b. Tabular } \\
\text { sandstone }\end{array}$ & $\begin{array}{l}\text { Fine to very fine sandstone } \\
\text { Tabular beds }(2-20 \mathrm{~cm} \text { thick })\end{array}$ & $\begin{array}{l}\text { Very well sorted } \\
\text { Nonerosive base }\end{array}$ & $\begin{array}{l}\text { Overbank deposits } \\
\text { within the floodplain } \\
\text { (Bridge, 1993, 2009) }\end{array}$ \\
\hline F6. Siltstone & $\begin{array}{l}\text { Siltstone to claystone } \\
\text { Homogeneous units } 1-10 \mathrm{~m} \text { thick } \\
\text { Intercalated carbonate beds with } \\
\text { nodules } 1-5 \mathrm{~cm} \text { in diameter }\end{array}$ & $\begin{array}{l}\text { Very well sorted } \\
\text { Fine and regular horizontal } \\
\text { laminations } \\
\text { Small particle size variation }\end{array}$ & $\begin{array}{l}\text { Floodplain or distal } \\
\text { fine-grained sediment } \\
\text { on alluvial-fan lobes } \\
\text { (Bridge, 2009) }\end{array}$ \\
\hline
\end{tabular}




\subsection{FA1 facies association: Alluvial fan dominated by hyperconcentrated flows}

The FA1 facies association includes F1a chaotic breccia (60\%; Fig. 3a) and F1b finegrained breccia (40\%) (Table 1) that form amalgamated bodies ranging in thickness from several to several tens of meters. These deposits are characterized by a short transport distance and a relatively close source. The FA1 facies association is interpreted as related to hyperconcentrated flows (Pierson and Scott, 1985; Benvenuti and Martini, 2002). This type of alluvial fan represents $\sim 80 \%$ of those identified in the Bidarray Basin. They are characterized by slopes of $1^{\circ}$ to $12^{\circ}$ and a length/width ratio greater than 1 (Blair and McPherson, 1994; Chamyal et al., 1997). The hyperconcentrated flows resulted from the evolution of debris flows towards a turbulent flow and a sedimentary dynamic dominated by traction flow (Pierson and Scott, 1985; Benvenuti and Martini, 2002). The F1b breccias also were deposited by hyperconcentrated flows and form the distal part of the alluvial fans. The down-fan decrease in flow velocity allowed preservation of the coarse matrix of the F1a facies and left the largest clasts upstream.

\subsection{FA2 facies association: Debris-flow alluvial fan}

The FA2 facies association consists of F2a matrix-supported breccia (65\%; Fig. 3c), F2b muddy breccia (30\%; Fig. 3d) and F1c cemented breccia (5\%; Fig. 3b) (Table 1). These breccias are organized in a succession of amalgamated layers many decimeters in thickness. They are characterized by a short transport distance and a relatively close source. The FA2 facies association corresponds to debris-flow alluvial fans (Blair and McPherson, 1994; Iverson, 1997). The relatively small proportion of matrix in the F2a facies $(<40 \%)$ tends to indicate that this type of debris flow is noncohesive, whereas the larger proportion of matrix in the F2b facies $(>60 \%)$ tends to indicate that this type of debris flow is cohesive (Blair and McPherson, 1994; Levson and Rutter, 2000). FA2 deposits represent $20 \%$ of the alluvial fans 
identified in the Bidarray Basin. They are characterized by steeper average slopes than FA1 alluvial fans $\left(4-25^{\circ}\right)$ and a length/width ratio of 1 or less (Viseras et al., 2003). This type of alluvial fan has no middle part and transitions to a channelized system. Their watersheds $\left(<10 \mathrm{~km}^{2}\right)$ are smaller than those of hyperconcentrated fans $\left(>10 \mathrm{~km}^{2}\right)$ (e.g., Levson and Rutter, 2000; Leleu, 2005).

\subsection{FA3a facies association: Coarse fluvial}

The FA3a facies association includes F3a polygenic conglomerate (80\%; Fig. 3e) and F4 lenticular stratified breccia (20\%) (Table 1). These coarse deposits form units with thicknesses ranging from $2 \mathrm{~m}$ to $8 \mathrm{~m}$. The conglomerate is interpreted as bedload deposits within braided fluvial channels (Miall, 1977a, 1977b; Rust, 1978; Bridge, 1993, 2009). The stratified sandstone in the conglomerate is interpreted as high-flood deposits underlying the previous conglomerates that filled the fluvial channel (Rust, 1978). This facies association is mostly composed of fluvial channels characterized by southward sediment transport, evidenced by five paleocurrent measurements in the F3a facies between $\mathrm{N} 170^{\circ}$ and $\mathrm{N} 200^{\circ}$ (Fig. 2), consistent with paleocurrent directions reported by Boissonnas et al. (1974) and Lucas (1985). The F4 breccias commonly erode FA3b floodplain deposits, which correspond to fine-grained fluvial channelized deposits. The lateral extent of these channels is several tens of meters, and facies follow each other by forming thinning- and fining- upward sequences.

\subsection{FA3b facies association: Floodplain}

The FA3b facies association is characterized by a large proportion of F6 red siltstone and minor carbonate siltstone (70\%), intercalated with F5b tabular sandstone with thicknesses ranging from $2 \mathrm{~cm}$ to $20 \mathrm{~cm}(30 \%)$ (Fig. 3h; Table 1). Units of this facies association are 1 to $12 \mathrm{~m}$ thick and record the deposition of unconfined flows in a floodplain. The siltstone beds 
are deposited at the distal end of each flow by decantation mechanisms (Bridge, 1993, 2009). These are the most distal Permian deposits identified in the basin. The depositional environment of FA3b corresponds to a floodplain threaded with isolated low-energy channels.

\subsection{FA4 facies association: Braided fluvial}

The FA4 facies association is interpreted as braided fluvial channel deposits of Late Triassic age (Miall, 1977a, 1977b; Rust, 1978; Bridge, 1993, 2009). It is made up of equal parts F3b monogenic conglomerate (Fig. 3f) and F5a coarse amalgamated sandstone (Fig. 3g). These deposits form units with thicknesses ranging from $5 \mathrm{~m}$ to $40 \mathrm{~m}$ in which basal monogenic conglomerate with quartzite pebbles gradually gives way upward to coarse amalgamated sandstone. Imbricated pebbles record strong paleocurrents (Bridge, 1993), and oblique cross-stratification corresponds to pebbly dune cross-beds formed during migration through the fluvial channel or to large-scale low-angle stratification within a fluvial bar (Miall, 1977b). The 3D cross-stratification in the F5a sandstone corresponds to dune migration and aggradation within fluvial channels (Miall, 1977a). The major differences from the Permian FA3a coarse fluvial facies association are its monogenic pebbles, greater pebble size, and greater bedform thickness. These observations indicate the development during Triassic time of a much larger basin than the Permian basin. This is reflected by the reworking of quartzite pebbles within a fluvial system with amalgamated braided channels, characterized by a gentler sedimentary slope than during Permian time. The Triassic depositional system may differ from the Permian one in having (1) a different sedimentary source that was limited to reworked Cambrian-Ordovician quartzite and (2) a greater transport distance and potentially climatic changes that may explain the preferential preservation of the most stable clasts (quartzite pebbles). 


\section{Tectono-sedimentary analysis}

\subsection{Facies distribution of Permian deposits (FA1 to FA3)}

We made three correlation transects across the Bidarray Basin, based on logged sections at 12 localities, in order to estimate the remnant thickness and facies variations of the Permian deposits, despite the paucity of stratigraphic markers inherent to continental deposits (Fig. 4). The base of the Triassic conglomerate facies association (FA4) was taken as a datum for correlation as it forms a continuous surface at the top of the Permian deposits in all sections. It is a major erosive unconformity, and we therefore cannot exclude the possibility that parts of the uppermost Permian deposits were eroded. In any case, the early phase of basin fill is well preserved. Thickness variations are constrained by the basal Permian unconformity recognized at the base of most sedimentary sections. Log 12 is schematic and represents a composite section from the northern part of the basin.

The E-W transect provides a transverse section of the Bidarray Basin at its north end (Fig. 4b). In the western part (Log 1), the Permian deposits are composed of alluvial fans characterized by hyperconcentrated flows (FA1) that pass laterally to a coarse fluvial system (FA3a; Log 11). The easternmost part of this transect ( $\log 12)$ is characterized by finergrained facies with a predominance of floodplain deposits (FA3b). This transect documents an eastward direction of sedimentary transport, an eastward increase of subsidence and an unconformity between the Permian deposits and the Paleozoic substratum.

Two N-S trending transects extend along the eastern and western parts of the Bidarray Basin, respectively (Figs. 4a and 4c). In the western transect (Fig. 4c), the thickness of the Permian deposits varies between 0 and $200 \mathrm{~m}$, decreasing towards the south. Breccias derived from hyperconcentrated flows within alluvial fans (FA1) are present in the northern 
part of the transect (Logs 1 and 2), along the contact with the Cinco-Villas Variscan substratum, and coarse-grained fluvial deposits (FA3a) dominate in the southern part (Logs 3 and 4).
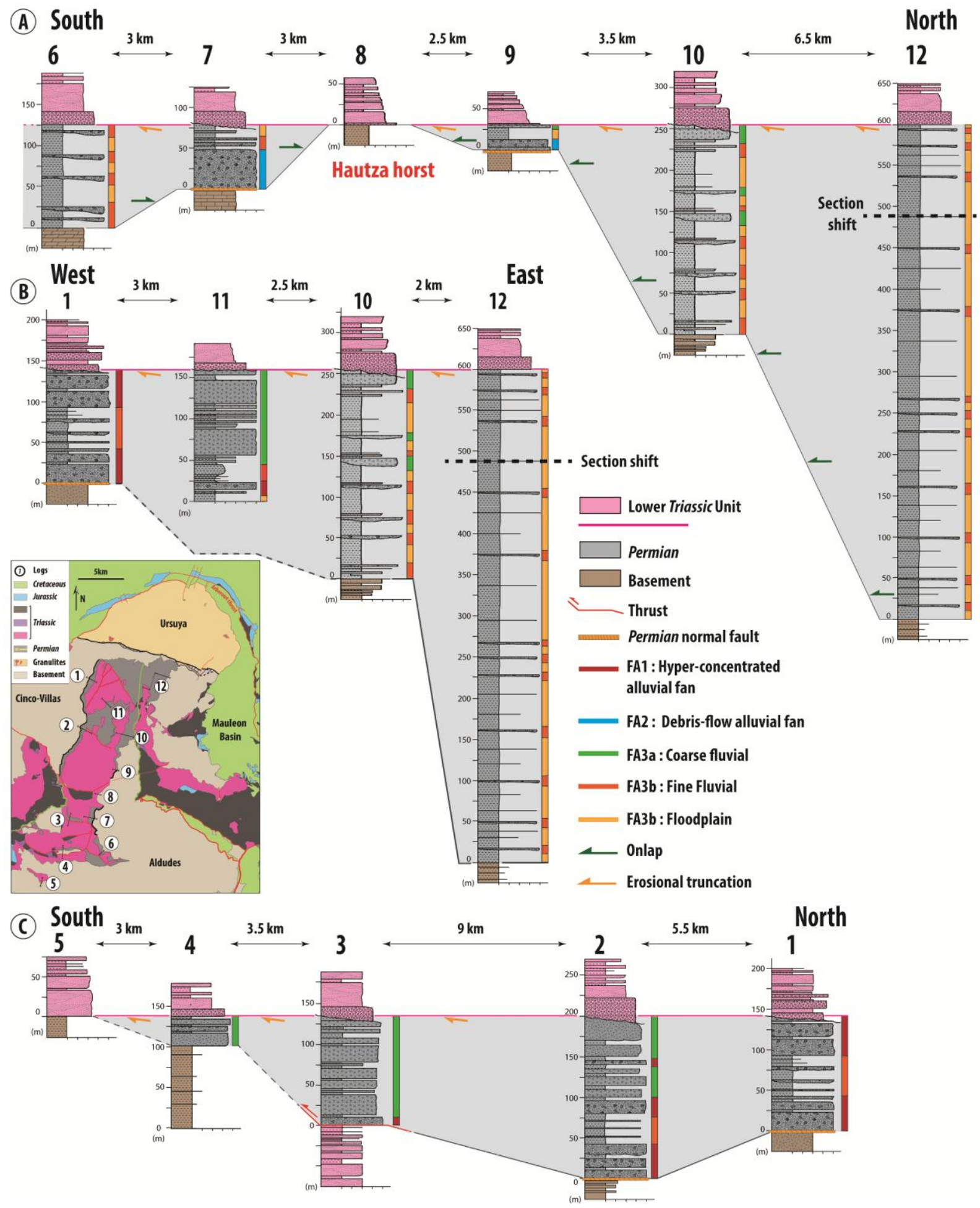
Fig. 4. Correlation transects showing the facies structure of the Permian Bidarray Basin. Locations of logged sections are shown in the inset map. Facies associations are represented as colored columns to the right of each log. (A) Eastern transect: this part of the basin is characterized by distal facies, as shown by the dominance of the FA3 facies association (fluvial and floodplain deposits). The Permian deposits thin towards Log 8, where they disappear and the Triassic basal conglomerates are absent. The presence of alluvial fan deposits (FA2) on both sides of Log 8 is suggestive of a tectonic control (a Permian horst; see discussion in the text). (B) West-east transect: the Permian sedimentary system thickens to the east and is increasingly characterized by distal facies. (C) Western transect: the Permian facies are relatively proximal and thin towards the south. At the southern end, Permian strata are completely eroded and the basal Triassic conglomerates are absent.

The eastern transect is characterized by predominantly distal facies associations, specifically FA3b floodplain deposits (Fig. 4a). However, thicknesses range widely, from $0 \mathrm{~m}$ to $600 \mathrm{~m}$, along this transect. The Permian sequence is thickest in the northern part of the basin, around the location of composite $\log 12$. It thins towards $\log 8$, where no Permian deposits are preserved. Because Log 8 has debris-flow alluvial fans (FA2) on both adjacent logs, it is interpreted as a structural high during Permian time, the so-called Hautza horst.

Chaotic breccias (facies F1c, Table 1) are only present north of the Louhossoa fault, where they lie unconformably on the Cambrian-Ordovician metasedimentary cover of the Ursuya granulites. The F1c facies is analogous to the Permian-Triassic deposits, as evidenced by its position overlying the Paleozoic substratum, its red matrix and its continental sedimentary environment. We interpret these rocks as the most proximal and poorly sorted of the Permian breccias (Fig. 3B). The angular shape of the clasts, derived from the Paleozoic substratum, indicates very short sediment transport distances and close sources (Table 1). 


\subsection{Facies distribution of the Triassic deposits (FA4)}

The Triassic conglomerates lie unconformably on the Permian sequence. Along the Iparla cuesta (Logs 9 and 10), the Permian strata appear to have been slightly tilted towards the NNE prior to the Triassic erosional truncation (Fig. 3i). Indeed, part of the variations in thickness of the Permian deposits can be related to this pre-Triassic erosion. The erosional surface dips towards the SSW (Fig. 3i). The Triassic conglomerates pinch out towards the Hautza horst $(\log 8)$ whereas they can reach more than $40 \mathrm{~m}$ in thickness everywhere else. These variations in thickness of the Triassic conglomerates argue in favor of activity of the Hautza horst that continued from Permian into Triassic time.

\subsection{Permian to Triassic morphotectonics of the Western Basque Pyrenees}

The distribution and geometries of sedimentary facies show that the Permian Bidarray Basin was a narrow continental basin, trending $\mathrm{N} 10-20^{\circ}$, of which the main paleogeographical trends are still preserved. The tectonically controlled borders of this extensional basin are characterized by two types of alluvial fan systems (FA1 and FA2). The western margin is dominated by FA1 alluvial fans aligned in the N10-20 direction along the contact with the Devonian-Carboniferous rocks of the Aldudes massif. The N-S Artzamendi normal fault, dipping steeply towards the east, separates the area of high relief to the west and the Permian intracontinental basin to the east. The FA1 alluvial fans grade eastward to a coarse longitudinal fluvial system (FA3a) and floodplain (FA3b). Paleocurrent measurements show that the fluvial system is parallel to the axis of the basin and orthogonal to the eastward growth direction of the alluvial fans.

Debris-flow alluvial fans (FA2) are present in the southeastern part of the basin, close to $\log 8$ (Fig. 4). The occurrence of these alluvial fans together with the thinning of the Permian sequence suggest that this area corresponds to a synsedimentary horst structure (Fig. 
4a). This horst seems to have been active until the Carnian, as shown by the hiatus in the basal Triassic conglomerates $(\log 8)$. These alluvial fans are characterized by smaller drainage areas and steeper slopes than the FA1 alluvial fans on the western margin of the Permian basin. Further south, the Bidarray Basin margin does not appear to be preserved. Permian deposits thin towards the SSW beneath the Triassic erosional unconformity, which is roughly horizontal, and the presence of a thrust contact between the Permian and Triassic deposits in the south (Fig. 4c) suggests that the original thickness of the Permian deposits cannot be fully constrained. The thickness variations of the Permian deposits may reflect both Permian differential subsidence and NNE tilting before deposition of the Carnian conglomerates.

The easternmost Permian deposits are characterized by distal fine-grained fluvial and floodplain facies, which make up the greatest thickness of Permian deposits in the basin, and by their onlap over the Variscan substratum. Two hypotheses can be proposed to explain the geometry of the eastern part of the Permian Bidarray Basin: (1) the basin is a half-graben controlled by the Artzamendi normal fault to the west and (2) the basin is a graben controlled by the Artzamendi fault and a conjugate eastern normal fault that is now concealed by Late Cretaceous calcareous turbidites lapping onto the Variscan substratum (Fig. 2).

\section{Structural scheme of the Basque massifs}

The present-day structure of the Permian basin and its relationship with the adjoining Basque massifs are illustrated in Figure 5 by 6 cross-sections that are based on the 12 logged sections. The Permian deposits of the Bidarray Basin are preserved in the center of this present-day horst structure, where they are exposed along a syncline oriented N10-20 that is bordered to the west by a line of alluvial fans. Cross-sections 1 to 4 show the thickest Permian successions. Cross-section 5 displays the unconformity of the Triassic deposits particularly well, where the Permian deposits thin out to the east with steeper dips $\left(20-25^{\circ}\right)$ than the 
overlying Triassic rocks $\left(10-15^{\circ}\right)$. The N-S cross-section 6 shows that towards the south, the Permian deposits are thinner and the Triassic sequence lies directly on the Paleozoic rocks. In cross-sections 2 to 5, Triassic deposits lie directly upon Paleozoic rocks on the east side. The FA3a facies association, corresponding to the longitudinal fluvial drainage system of the Permian basin, is located in the center of the syncline and the floodplain deposits (FA3b) onlap the Devonian-Carboniferous substratum to the east (cross-sections 2 to 5). Crosssection 5 also shows the FA2 debris-flow alluvial fans near the Hautza horst. Southward propagating minor thick-skin tectonics, visible in $\mathrm{N}-\mathrm{S}$ cross-section 6 , is responsible for the formation of $\mathrm{N} 90-110^{\circ}$ folds, and related minor thrusts have tilted the Permian-Triassic deposits northward in the southern part of the basin.

The tilting of the Permian deposits and the subsequent Triassic erosive unconformity indicate that the tilt is pre-Triassic (pre-Carnian). The east-dipping Bidarray normal fault has a $\mathrm{N} 0-10^{\circ}$ orientation within the Bidarray Basin and a $\mathrm{N} 120-150^{\circ}$ orientation along the Aldudes massif to the south (Fig. 2). This normal fault is responsible for the southwestward tilting of the Lara-Jara massifs, clearly visible in the Triassic sequence (Figs. 2 and 5). The Bidarray fault also affects the lower to middle Jurassic limestones in the area and the latest Albian to Cenomanian St.-Etienne de Baïgorry breccias (Merle, 1974). The offset of the Bidarray fault is interpreted as being of Cenomanian age (Saspiturry et al., 2019). Helium thermochronometric data from zircon reveal elevation-invariant ages of ca. $98 \mathrm{Ma}$ in the Mauléon Basin and a pronounced inversion point along the Bidarray fault (Hart et al., 2017). Thus, the proximal margin recorded rift-related exhumation and cooling at ca. $98 \mathrm{Ma}$. Offset on the fault increases southward from $300 \mathrm{~m}$ near cross-section 1 to $3000 \mathrm{~m}$ in cross-section 5 (Fig. 5). The west-dipping Errazu normal fault is responsible for the eastward tilting of the Peñas de Betarte (cross-section 5, Fig. 5). Its estimated offset of about $2700 \mathrm{~m}$ is similar to that of the Bidarray fault, and it affects Late Triassic deposits, indicating that its offset postdates the 
Triassic. An analogy with the Bidarray fault suggests an Albian-Cenomanian age for offset on the Errazu fault. The Errazu and Bidarray normal faults are thus probably responsible for the formation of the Bidarray synform.

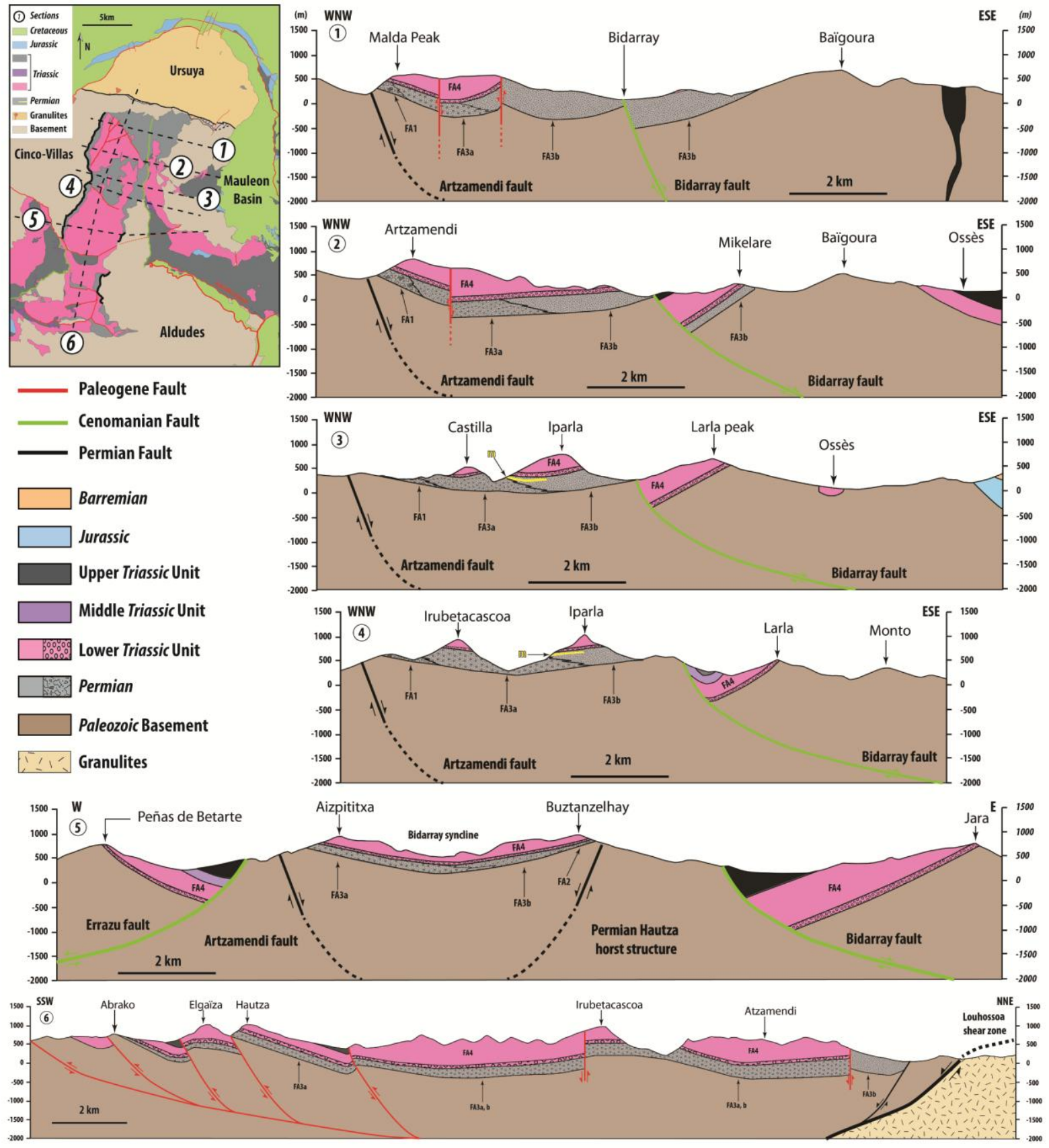

Fig. 5. (1-5) W-E cross-sections of the Bidarray Basin, showing the current structural scheme of the Basque Pyrenees. The Basque massifs form a large horst structure with a central syncline holding Permian-Triassic deposits. Cenomanian offset on the Bidarray fault affects 
the eastern part of the basin, and its offset decreases northward towards the Ursuya granulites. Late Permian alkaline magmatism is signified by a yellow line labeled " $\mathrm{m}$ " in cross-sections 3 and 4. (6) N-S cross-section of the Bidarray Basin, showing the tabular structure of the Upper Triassic sequence over a Permian sequence tilted towards the NNE. The Permian-Triassic deposits are monoclinal and are affected by a small amount of Tertiary deformation (southward thrusting). The Louhossoa shear zone separates the Permian basin from the Ursuya granulites. No vertical exaggeration.

\section{Structural analysis of the Ursuya granulitic unit}

The outcropping part of the Ursuya massif corresponds to the southern half of a gneiss dome (Boissonnas et al., 1974), characterized by foliation planes oriented E-W and dipping roughly south (Figs. 2 and 6). Outcrops expose a nearly continuous section of the dome, from the granulites and associated bodies of diorite and peridotite in its core to its metasedimentary envelope.

The foliation that defines the gneiss dome is highlighted by alternating leucosomes and paragneisses (Fig. 7a) made of garnet-sillimanite-biotite-feldspar-quartz aggregates. It corresponds to the most common granulitic paragenesis in the massif (Figs. $7 \mathrm{~b}$ and c). Biotite is uncommon in the granulites. As reported by Boissonnas et al. (1974), the surrounding migmatitic gneisses contain cordierite that forms coronas around granulitic garnets (Fig. 7d), which is typical of decompression during metamorphism (Vielzeuf, 1984). Sillimanite and biotite are more abundant in the migmatitic gneiss than in the granulitic gneiss. The foliation planes in both granulites and migmatites have mineral-stretching lineation manifested as quartz ribbons, elongated feldspar, fibrolitic sillimanite and biotite aggregates. This lineation has an E-W trend in the northern and central parts of the massif that changes gradually to a $\mathrm{N} 120-130^{\circ} \mathrm{E}$ trend in the southern part of the massif (Fig. 2). We observed predominantly 
symmetrical boudinage in the foliation (Fig. 7a) and locally double boudinage, suggesting a flattening component in the finite strain. The $\mathrm{C}^{\prime}$ shear bands bear striae-lineations parallel to those in the host rocks, and garnet sigma-clasts attest to local noncoaxial top-to-the-east or southeast shear (Figs. 6a, 6b and 7b).

The southernmost and easternmost parts of the gneiss dome display the transition between migmatites or paragneisses (sillimanite-orthoclase zone) and low-grade Ordovician sediments (chlorite zone) (Fig. 2). This transition is characterized in the field by highly laminated paragneisses, mica schists, and metaquartzites (Figs. 6, 7e and 7f) hosting discontinuous marble layers and highly sheared pegmatites. The transition forms a regionalscale shear zone called the Louhossoa shear zone (Figs. 2 and 6). This shear zone is mainly localized within the andalusite-biotite-staurolite zone and is $\sim 500 \mathrm{~m}$ thick (Figs. 2 and 6). The best descriptions of this shear zone can be made in the southeastern part of the massif, where all the structural levels are observed (Fig. 6d). Elsewhere, outcrops are poor and observations are limited to scattered point exposures.

In the southern flank of the gneiss dome, mineral and stretching lineations within the shear zone take the form of quartz ribbons and biotite aggregates and turn progressively from a NW-SE to a N-S trend (Fig. 2). As in the core of the gneiss dome, deformation is marked by flattening but is also associated with $\mathrm{C}^{\prime}$ shear bands showing a dominant non-coaxial top-tothe-south sense of shear (Figs. 6 and 7e). The mylonitic foliation is parallel with the regional foliation, forming a single fabric mainly defined by high-grade parageneses (sillimanite, andalusite, biotite, K-feldspars; Fig. 7e). Within phyllonitic layers, chlorite is formed at the expense of biotite, which shows that deformation occurred under retrogressive conditions (Figs. 7f and 7g). Upward within the chlorite zone, this mylonitic foliation, characterized by millimeter-scale alternating dark and light layers with no visible grains (Fig. 7h), evolves into 
a pervasive crenulation cleavage, progressively preserving the original bedding of Ordovician sandstones (Fig. 7i). The crenulation cleavage dips gently to the south or is subhorizontal, remaining roughly parallel to the foliation within the shear zone (Fig. 6d). Over a distance of $200 \mathrm{~m}$ upward, in Paleozoic rocks, the cleavage disappears and only a poorly expressed crenulation lineation remains. In the southwestern part of the massif, the Itxassou microgranite intrudes the transitional zone between the migmatites and the low-grade Ordovician quartzite within the shear zone (Figs 2 and 6c). The pluton displays no magmatic or gneissose fabric and is only affected by jointing (Fig. 7j). The easternmost part of the Ursuya massif displays a similar sharp transition from migmatitic gneiss to chlorite-bearing mica schist and quartzite (Figs. 2 and 6a). A few hundred meters below this transition, the foliations turn to NE-SW or N-S and dip moderately to the east (Fig. 6a). Stretching lineations remain roughly E-W through the transition. In mica schist, meter-scale late folds showing mostly E-W and N-S axial planes and moderately plunging fold axes are superimposed on this first-order trend. As noted by Boissonnas et al. (1974), the transitional zone between highgrade and low-grade rocks corresponds to a shear zone containing highly laminated gneisses and mica schists. The apparent thickness of this transitional zone (the andalusite-staurolite zone) is highly variable (from $\sim 200$ to $0 \mathrm{~m}$ ), and the shear zone appears to be a subtractive feature. Unfortunately, our observations here were limited to float rocks, and we were unable to make a detailed structural analysis of the shear zone in this area. Immediately above it, we observed Permian chaotic breccias of facies F1c (see Figs. 3b and 6a). This tectonic contact appears mostly eroded and is unconformably overlapped by Santonian deposits. This subtractive contact might be continuous as a part of it is preserved in the southeastern part of the massif (Fig. 2). We thus interpret it as a single extensional low-angle shear zone (Louhossoa) across the whole gneiss dome. 
The whole massif is affected by late brittle deformation in the form of faults with variable orientations and kinematics. The first set consists of $\mathrm{N}-\mathrm{S}$ to $\mathrm{N} 45^{\circ} \mathrm{E}$ trending normal faults (Figs. 6 and 7a). A second set consists of E-W trending south-dipping normal faults, parallel to and merging into the Louhossoa shear zone (Figs. 2 and 6d). A few of these latter faults also show reverse (top-to-the-north) kinematics, suggesting Alpine (re)activation of earlier normal faults (Figs. 6b and d) or reactivation of bedding planes in the low-grade basement (Fig. 6c). The reverse faults are responsible for the folding or westward tilting of the eastern termination of the gneiss dome and the Louhossoa shear zone (Fig. 6a).
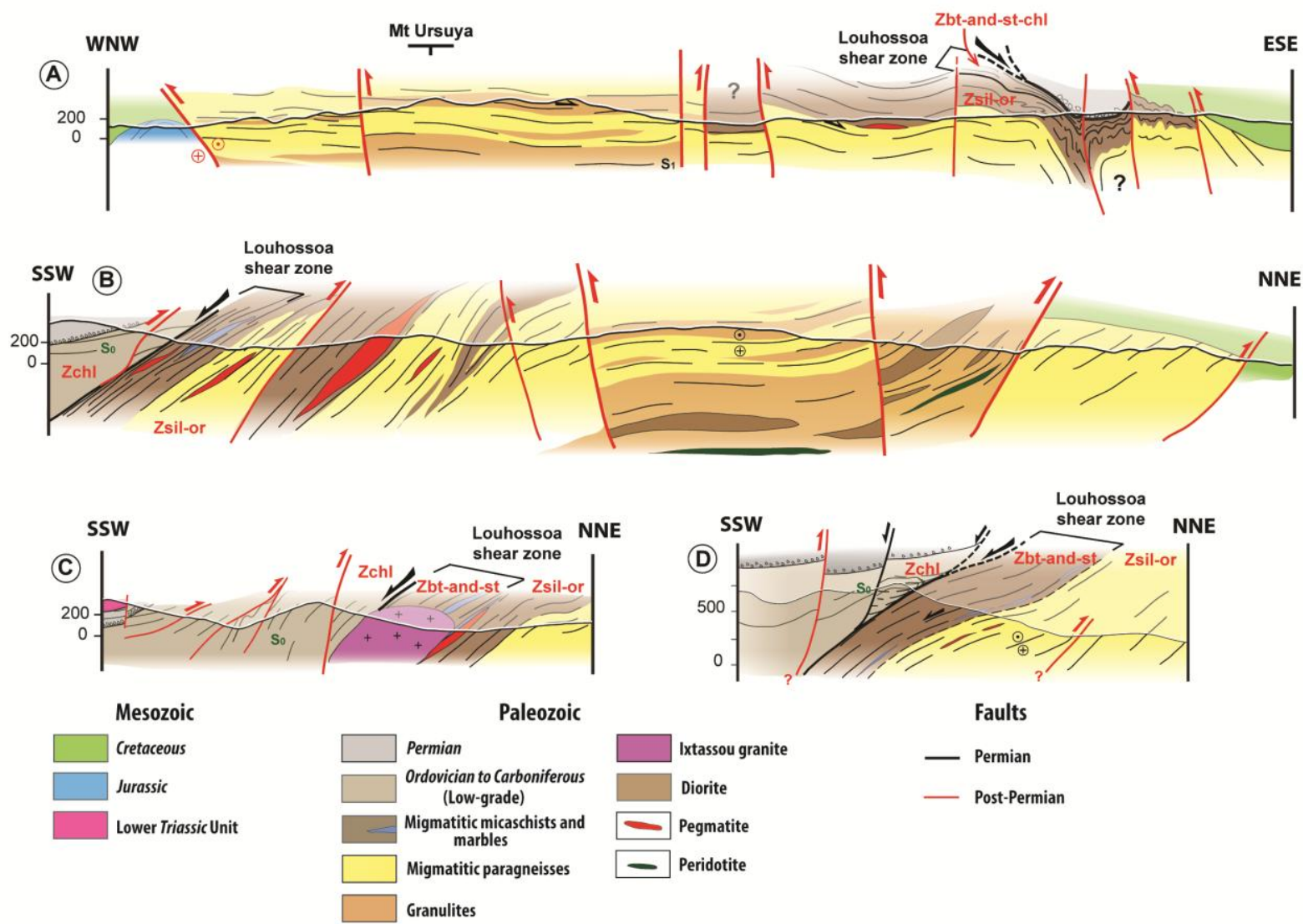

Fig. 6. Cross-sections of the Ursuya gneiss dome (locations in Fig. 2): (A) E-W cross-section of the whole massif, (B) N-S cross-section of the central part of the gneiss dome, (C) N-S cross-section of the southwestern limb, (D) N-S cross-section of the southern limb. Zbt-andst, biotite-andalusite-staurolite zone; Zchl, chlorite zone; Zsil-or, silllimanite-orthoclase zone. 

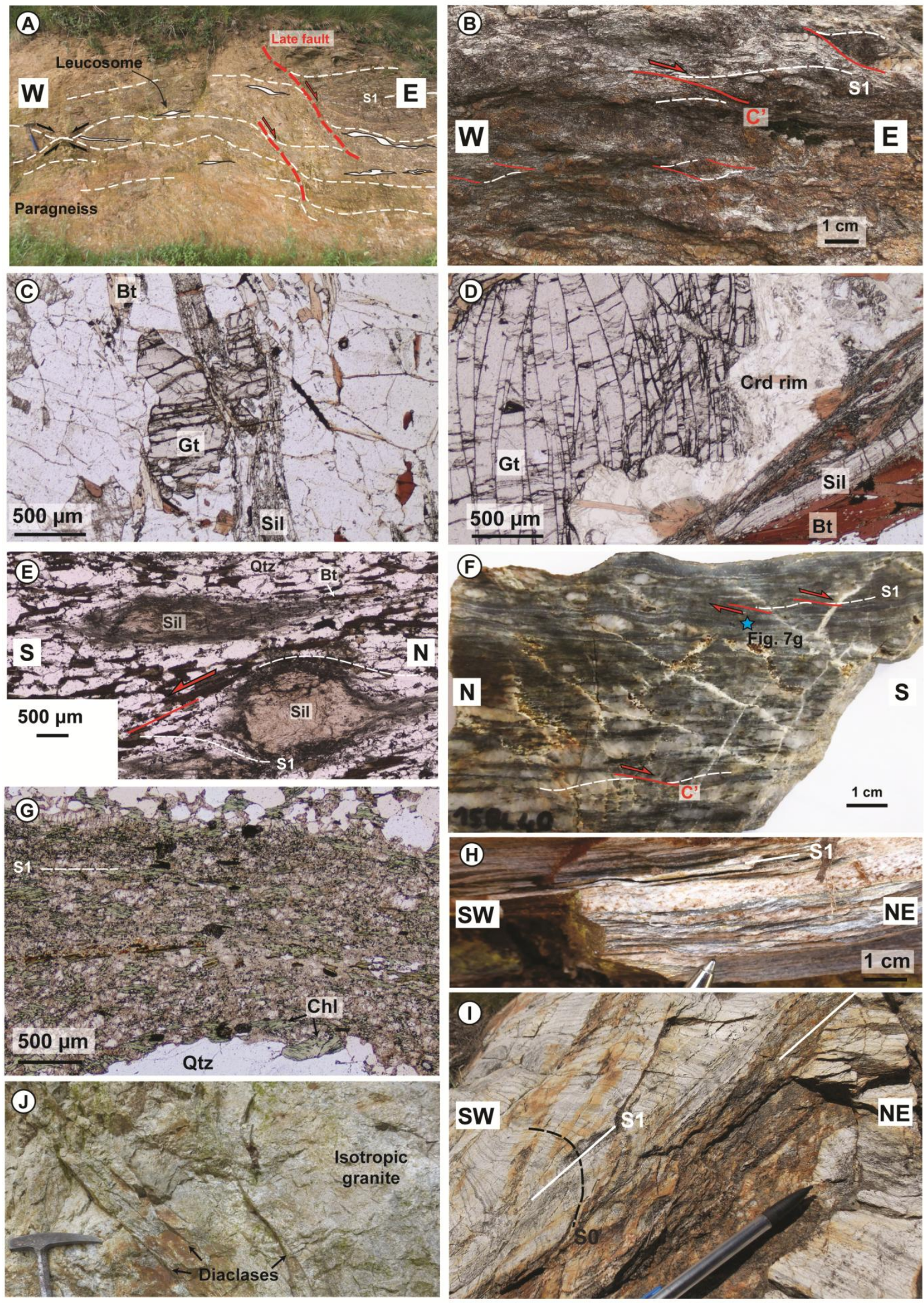
Fig. 7. Images of typical petrology and deformation in the Ursuya massif. (A) Subhorizontal foliation within migmatite, affected by symmetrical boudinage and late normal faults. (B) Top-to-the-east shearing in coarse-grained pelitic granulite (kinzigite) at Mt. Ursuya. (C) Photomicrograph of granulite facies paragneiss, showing scarce remnant biotite. (D) Photomicrograph of granulitic gneiss showing an altered cordierite corona around garnet, and abundant sillimanite and biotite. (E) Photomicrograph of sillimanite porphyroclasts within the Louhossoa shear zone showing top-to-the-south kinematics. (F) Top-to-the-south shearing in quartzite within the Louhossoa shear zone. (G) Photomicrograph of a phyllonitic layer in the quartzite of Fig. 7F, showing abundant chlorite formed at the expense of biotite. $(\mathrm{H})$ Highly sheared metasediments at the top of the Louhossoa shear zone, within the chlorite zone. (I) Crenulation cleavage and bedding in Ordovician sandstone in the hanging wall of the Louhossoa shear zone belonging to the chlorite zone. (J) Itxassou granite showing isotropic fabric and jointing.

\section{Discussion}

\subsection{Permian age of the Louhossoa shear zone}

We propose that the Louhossoa shear zone is a detachment that was activated during the Permian development of the Bidarray Basin, for the following reasons:

(1).Deformation within the granulites and migmatites occurred at high temperature as indicated by high-grade parageneses such as sillimanite, K-feldspars, andalusite, garnet and biotite. The appearance of cordierite around granulitic garnets within the migmatitic gneisses implies decompression (see Vielzeuf, 1984) during syn-melt penetrative top-tothe-east shear. 
(2).We observed a single consistent fabric from the granulite to the chlorite-bearing Ordovician metasediments in the field and in thin sections. The retrogressive deformation within the Louhossoa shear zone suggests a continuous exhumation history during a single tectonic phase.

(3).U-Pb ages from the Ursuya massif (Hart et al., 2016; Vacherat et al., 2017) indicate that granulites and paragneisses crystallized and were deformed between 295 and $274 \mathrm{Ma}$.

(4). The Itxassou pluton intrudes the southern part of the metamorphic series, where deformation was localized, but remains isotropic. It is thus post-kinematic and its age of emplacement $(276.8 \pm 1.9 \mathrm{Ma}$; Vacherat et al., 2017) provides a minimum age for the deformation along the shear zone.

(5). The eastern part of the Louhossoa shear zone is unconformably covered by Santonian calcareous turbidites, precluding a later activation or reactivation (Fig. 2).

These observations do not support an activation of the Louhossoa shear zone in Albian to Cenomanian time during the last rifting phase before Pyrenean orogeny, as proposed by Jammes et al. (2009).

\subsection{Conceptual model of Permian crustal thinning}

A geodynamic conceptual model of continental crustal thinning is proposed to explain the development of the Bidarray Basin as part of a Permian rift system (Fig. 8). The development of this continental basin is of the same age as the exhumation of the Ursuya granulites (Hart et al., 2016). All of these structural and magmatic processes are interpreted as being related to a single extensional tectonic phase between ca. 300 and $275 \mathrm{Ma}$. Several arguments support the interpretation of the Ursuya massif as a Permian extensional MCC resulting from regional thinning of hot lithosphere following collapse of the Variscan belt and subsequent delamination of the lithospheric mantle: 
(1). Granulite recorded decompression during penetrative E-W horizontal ductile flow, as highlighted by cordierite coronas around granulitic garnets.

(2). The exhumation of granulite and migmatite was then favored by strain localization within a retrogressive extensional shear zone such as the Louhossoa detachment, evolving from ductile shearing during partial melting to brittle normal faulting (Figs. 6 and 8).

(3). The E-W regional direction of stretching within granulites and migmatites (Fig. 2), compatible with the orientation of the active Bidarray graben, was favored by the activation of $\mathrm{N}-\mathrm{S}$ trending normal faults in the upper crust.

(4). The Bidarray continental basin developed on the hanging wall of the Louhossoa detachment (cross-section 6 in Fig. 5), the footwall being currently exposed in the Ursuya granulites (Fig. 6).

(5). The structurally controlled deposition of Permian redbeds appears to be coeval with HTLP granulite metamorphism, magmatism and HT deformation (Pereira et al., 2014; Hart et al., 2016; Vacherat et al., 2017). The alkaline volcanism in the center of the Bidarray Basin in the latest Permian (Lucas, 1985; Bixel and Lucas, 1987) may be the surface signature of the middle and lower crustal flow below the basin and may reflect regional thinning of the lithosphere induced by continental rifting. 


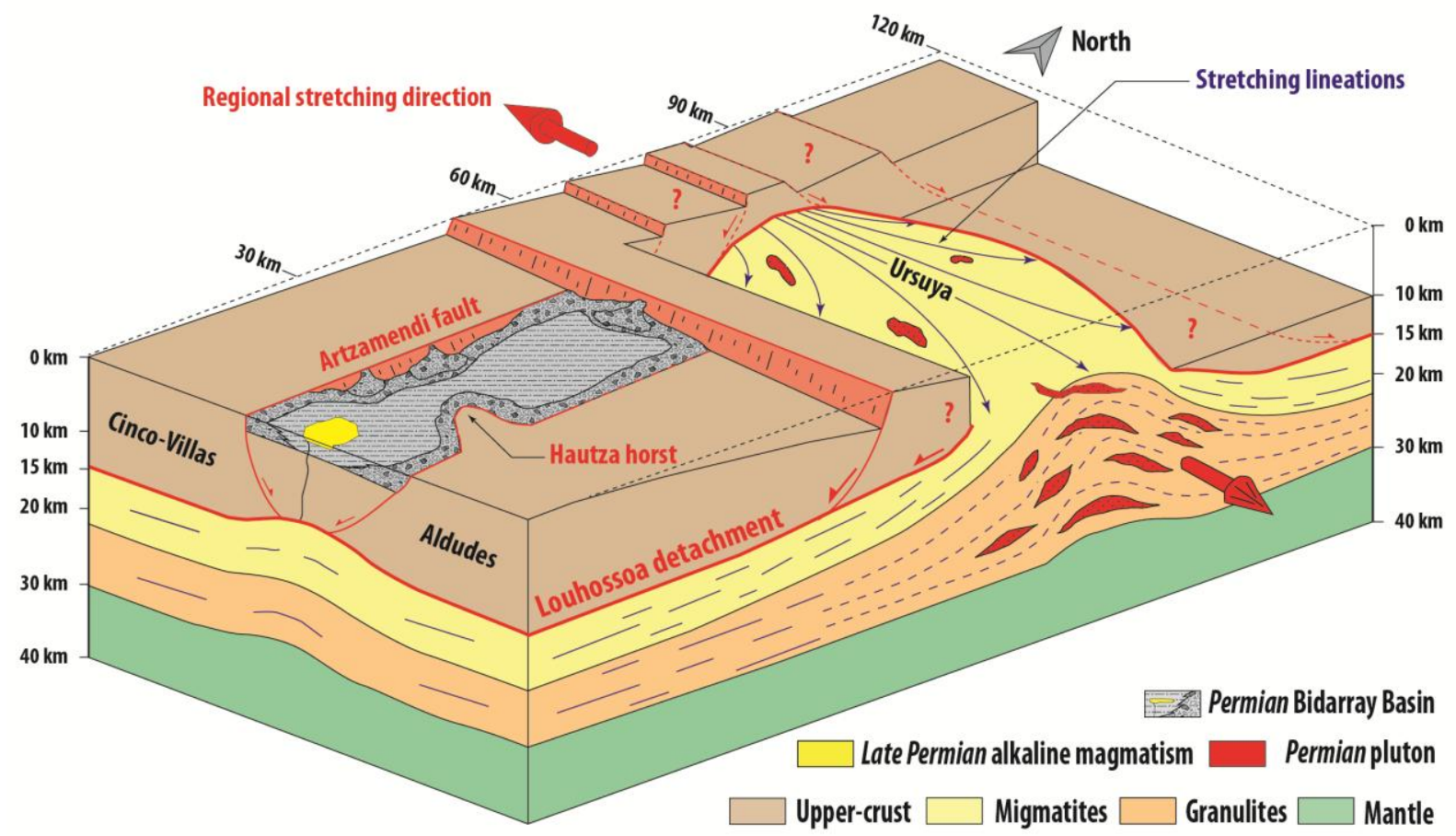

Fig. 8. Conceptual model of crustal thinning during Permian time. The N-S trending Bidarray Basin develops on the hanging wall of an "a-type" MCC, tectonically controlled by the Artzamendi normal fault and the Hautza horst. The Ursuya MCC is characterized by an E-W major stretching direction, as shown by the E-W top-to-the-east stretching lineation within the granulites. Near the Louhossoa detachment the stretching lineations take a top-to-the-south direction, showing a southward normal displacement along this major shear zone.

The development of the Permian basin and the genesis of the Ursuya MCC can be explained in two major phases. The first phase corresponds to pure shear thinning (sensu McKenzie, 1978) with the initiation of rifting by faulting in the upper crust while the partially molten lower crust is flowing longitudinally. This first phase of crustal thinning initiated the exhumation of granulites under melt-present conditions, as exemplified in migmatites by destabilization of granulitic garnet into cordierite (Fig. 7d, see also Vielzeuf, 1984). Second, gravitational instability induced by the buoyancy of molten lower crust at depth implies a vertical flow of the ductile crust towards the necking zone of the upper crust, initiating the 
development of an extensional MCC (Tirel, 2004; Tirel et al., 2004; Jolivet et al., 2008; Le Pourhiet et al., 2012; Brun et al., 2017). The exhumation of deep molten rocks is favored by strain localization within major shear zones, here the Louhossoa detachment, developed at the top of the melting front (the gneiss dome envelope) and the flank of the MCC.

In detail, the stretching lineations are mainly parallel to the elongation axis of the gneiss dome and the orientation of the Louhossoa detachment, indicating the "a-type" morphology of the Ursuya MCC (see Jolivet et al., 2004). Divergence of stretching lineations from the core to the limbs (Fig. 8) is common in "a-type" MCCs and simply reflects gravitational instabilities within the buoyant and partially molten mid-lower crust, leading to its exhumation (Jolivet et al., 2004; Augier et al., 2005; Le Pourhiet et al., 2012). As strain localization occurs within the dome envelope, these MCCs tend to have a symmetrical shape (Jolivet et al., 2004). The northern flank of the Ursuya MCC has not been preserved because of the overprint of the Arberoue thrust during Paleogene time (Fig. 2).

The Ursuya MCC appears to be immature, in that only low-grade Paleozoic rocks (CambrianCarboniferous metasediments) are reworked in the Permian and Triassic deposits. The Ursuya MCC retained a metasedimentary Paleozoic cover during Permo-Triassic time. However, we interpret the facies F1c chaotic breccias as Permian-Triassic sedimentary breccias derived from the top of the Louhossoa detachment (the Cambrian-Ordovician metasedimentary cover of the MCC). During Permian time, the Bidarray Basin was filled by continental deposits reworking the metasedimentary rocks of the MCC hanging wall (Devonian-Carboniferous metasediments). During Triassic time, the continental fluvial system changed sedimentary sources and reworked the thin remaining metasedimentary envelope of the Ursuya MCC (Cambrian-Ordovician quartzite). On the basis of our cross-sections (Figs. 5 and 6), we suggest that the metasediments above the high-grade rocks from the Ursuya massif were 
approximately $5 \mathrm{~km}$ thick at the end of the Triassic. Taking into account that the Late Triassic corresponds to a major rifting phase in Western Europe (e.g., Frizon de Lamotte et al., 2015) and that most $(>60 \%)$ of the rocks of the Upper Triassic unit in the study area are mantlederived magmatic rocks (ophites, see Fig. 2; Rossi et al., 2003), we infer that the geotherm was probably much greater than $30^{\circ} \mathrm{C} / \mathrm{km}$ at ca. $200 \mathrm{Ma}$. In magmatic rift systems, geotherms can easily exceed $100^{\circ} \mathrm{C} / \mathrm{km}$ locally (e.g., Omenda, 1997; Chandrasekharam et al., 2018) and are about $40-60^{\circ} \mathrm{C} / \mathrm{km}$ in many other rifts (e.g., Barnard et al., 1992; Ren et al., 2002; Ranalli and Rybach, 2005; Boone et al., 2018). We thus propose that a paleo-geotherm of about 50$60^{\circ} \mathrm{C} / \mathrm{km}$ at the end of the Triassic is reasonable. The $200 \mathrm{Ma}$ cooling age indicated by ${ }^{39} \mathrm{Ar} /{ }^{40} \mathrm{Ar}$ dates in the paragneisses of the Ursuya massif (Masini et al., 2014) suggest that the Ursuya high-grade rocks were probably exhumed up to 5-6 $\mathrm{km}$ depth during the Late Triassic (Fig. 8). PT estimates for granulites from other north Pyrenean massifs support this interpretation; for example, in the Saint Barthélémy massif in the Central Pyrenees (Fig. 1), deformation was mostly retrograde and led to the exhumation of granulite up to 2 kbar during the Late Carboniferous to Early Permian (de Saint Blanquat et al., 1990; de Saint Blanquat, 1993; Delaperrière et al., 1994; Lemirre, 2018). The Ursuya MCC recorded deformation patterns similar to those of transpressional gneiss domes elsewhere in the Pyrenees, such as (1) longitudinal horizontal flow of the partially molten middle and lower crust and (2) gradual strain localization at the top of the domes forming extensional shear zones with similar divergent lineation patterns (Cochelin et al., 2017, 2018b). But our study shows that the Basque massifs are the first documented example in the Pyrenees of Permian crustal thinning typical of an abnormally hot lithosphere permitting the formation of an MCC and its associated graben (Fig. 8). 


\subsection{Implications for the transition between the Variscan orogenic cycle and Pangea breakup}

The latest Carboniferous and earliest Permian (305-295 Ma) was a period of intensive reorganization of the collapsed Variscan belt in which mantle delamination led to the formation of several post-orogenic oroclines (e.g., Weil et al., 2010; Gutiérrez-Alonso et al., 2012). Our study suggests that the formation of the Ursuya MCC and Bidarray graben reflects the switch from dominant N-S convergence recorded in the Pyrenean Axial Zone from 310 to 290 Ma (during oroclinal bending; see Denèle et al., 2014; Cochelin et al., 2017; Lemirre et al., 2019) to overall E-W extension in the Pyrenean realm.

E-W extension in the Basque massifs is compatible with the interpretation of early and middle Permian basins in the eastern Pyrenees and Iberia as strike-slip basins (e.g., Gretter et al., 2015; Lloret et al., 2018). However, our study supports the interpretation that Permian deformation in the Pyrenees was characterized by homogeneous thinning of a hot crust rather than by strain localization into dextral mega-shear zones, as proposed by many authors (e.g., Muttoni et al., 2009; Domeier et al., 2012; Carreras and Druguet, 2014; Gretter et al., 2015). Our results suggest that the crust throughout the Pyrenees (the foreland of the Variscan belt) stayed hot and partially molten during early and middle Permian extension, as in other massifs in the previously collapsed hinterland of the Variscan belt, such as Corsica-Sardinia (e.g., Rossi et al., 2015; Gaggero et al., 2017), or in the Alps (e.g., Pohl et al., 2018). In this scenario, strain was vertically partitioned within the crust, with a homogeneously and longitudinally flowing lower crust and an upper crust affected by widespread $\mathrm{N} 20^{\circ} \mathrm{E}$ normal faults and longitudinal strike-slip faults.

Homogeneous thinning of the hot continental crust in the Pyrenees and Iberia during the Permian may have had a first-order importance for later localization of the main rift system of the Central Atlantic during the Early Jurassic and the breakup of Pangea in the 
Triassic (Sengör et al., 1984; Ziegler, 1990; Stampfli, 1996, 2012; Vai, 2003; Ziegler and Stampfli, 2001; Leleu et al., 2016). Indeed, homogeneous thinning within a hot lithosphere implies formation of wide rather than narrow rifts (Brun, 1999). We propose that the Pyrenean realm was part of the wide rift system recognized in the rest of Iberia during the Permian (e.g., Leleu et al., 2016). Therefore, Late Triassic to Early Jurassic extension and drifting that affected the cooled lithosphere may have been localized farther west within a narrower Permian-Triassic rift zone (Leleu et al., 2016) or along crustal-scale inherited structures (e.g., Le Roy and Piqué, 2001). The previously homogeneously thinned crust of the Pyrenees was later affected by Early Cretaceous hyperextension and mantle exhumation (Jammes et al., 2009; Lagabrielle et al., 2010; Masini et al., 2014; Teixell et al., 2016; Saspiturry et al., 2019).

\subsection{Tectonic implications for the structure of the Western Pyrenees}

Our study addresses the Permian-Triassic tectonic evolution of the northwestern Pyrenees. The Permian Bidarray extensional basin is relatively well preserved (Fig. 5), highlighting the small amount of deformation affecting this part of the Pyrenees during the Pyrenean orogeny. The basin is closely aligned with the putative transverse Pamplona fault, and its location coincides with the western and eastern edges of two branches of the Early Cretaceous Pyrenean rift system: the Mauléon and Basco-Cantabric basins, respectively (Fig. 2). The Bidarray Basin lies between two oppositely verging Cretaceous detachment faults (the Bidarray and Errazu faults) in a transfer zone corresponding to the Pamplona fault. Classically, the Pamplona fault is regarded not as a well-defined fault plane that can be observed at the outcrop scale, but as a broad crustal heterogeneity that controlled the opening of the Mauléon, Saint-Jean-de-Luz and Basco-Cantabric rift basins during Cretaceous extension and their alpine reactivation during the Cenozoic basin inversion (Schoeffler, 1982; 
Rat et al., 1983; Richard, 1986; Razin, 1989; Claude, 1990). We demonstrate in this study that during Permian time this transfer zone was characterized by a succession of N0-20 2 grabens affecting the upper crust (including the Bidarray Basin), separated by immature MCCs that exhumed middle and lower crust to shallow depths (including the Ursuya dome). Therefore, the Pamplona transfer zone appears to be a Permian inherited structure which was reactivated during Cretaceous rifting and was responsible for the shift towards the southwest of the Early Cretaceous Pyrenean rift axis.

Our crustal thinning model shows that, at the beginning of Cretaceous rifting, the Ursuya unit was characterized by a continental crust composed of granulitic mid-crustal rocks partially exhumed during Permian time. The Ursuya granulites were fully denudated and reworked during Cenomanian time in the Bonloc breccias, located under the Arberoue thrust (Fig. 2; Boissonnas et al. 1974; Claude, 1990). The perfect continuity of the Permian-Triassic paleogeographical and structural trends highlights the homogeneity of the Basque massifs, showing the absence of a major alpine discontinuity between the Cinco-Villas unit of European paleomagnetic affinity (Schott, 1985) and the Aldudes unit, part of the northern Iberian Cretaceous paleomargin (Schott, 1985). There is no physical continuity between the North Pyrenean fault as defined in the eastern and central Pyrenees (Choukroune, 1976) and interpreted as the tectono-magmatic axis of the Basco-Cantabric basin (Rat et al., 1983). The preservation of the original paleogeography and structure of the Bidarray Basin indicates that there was no major east-west Mesozoic strike-slip motion between the Iberian and European plates in this part of the Pyrenees (Schoeffler, 1965, 1982; Ducasse and Vélasque, 1988; Razin, 1989; Claude, 1990). Such strike-slip motion, deduced from plate kinematic reconstructions (Olivet, 1996; Rosenbaum et al., 2002; Sibuet et al., 2004), may have affected a more southerly area (Malod, 1982; Canérot, 2016) or may have been evenly distributed within the Cretaceous rift system. 


\section{Conclusion}

This sedimentological and structural study indicates that the Western Pyrenees record Permian E-W extension and a deformation pattern typical of a thinning hot lithosphere. We show that in the upper crust a N0-20 trending extensional basin (the Bidarray Basin) is filled by interdigitating alluvial fans that advanced towards a longitudinal fluvial system in the center of the basin. Coevally with the development of this intracontinental rift basin, the middle and lower crust was affected by (1) LP granulitic metamorphism (in the Ursuya dome), (2) horizontal flow parallel to the direction of extension in the sedimentary basin, and (3) ductile exhumation within an E-W elongated "a-type" MCC. The granulites were exhumed thanks to strain localization at the fusion front within an extensional shear zone (detachment) under retrogressive conditions. Our work shows that the Ursuya granulites were exhumed in several phases, first to upper crustal level during Permian rifting related to the Pangea breakup, then completed by denudation at the end of Cretaceous rifting. Formation of the MCC during Permian rifting implies that the entire Pyrenean realm was characterized at the time by an abnormally hot lithosphere. In such a hot context, deformation was mainly homogeneous, and strain was partitioned between horizontal flow in the lower crust and diffuse strike-slip and normal faulting in the upper crust rather than giving rise to regional strike-slip megashear zones. The Mesozoic Pamplona transfer zone appears as an inherited major crustal heterogeneity of Permian age and oriented N0-20 $0^{\circ}$ not visible at the outcrop scale as a single fault zone. Thus the main structures of Permian rifting appear to have controlled the development of Cretaceous rifting. The preservation of Permian-Triassic paleogeographic and structural patterns shows that a Mesozoic E-W strike-slip motion between the Iberian and European plates could not have taken place in this part of the Pyrenees. 


\section{Acknowledgments}

This work is part of the Orogen project, cofunded by Total and BRGM, and the RGF project funded by the BRGM. BC acknowledges funding from Labex Voltaire (ANR-10LABX-100-01), based at Orléans University and BRGM. We thank Orogen project managers Sylvain Calassou (Total), Emmanuel Masini (Total), Olivier Vidal (CNRS) and Isabelle Thinon (BRGM). Many thanks to Michel de Saint Blanquat for fruitful discussion about the geological background of the study area. The manuscript was greatly improved by reviews from Céline Ducassou and Jean Van den Driessche, whom we thank for their helpful comments. 


\section{References}

Adler, R. E., H. U. Boer, H. Jordan, K. Klarr, H. F. Krausse, D. Muller, R. Muller, H. Requadt, H. Roth, and J. Thiele, 1972, Carte géologique de l'Espagne au 1/50000; feuille de Valcarlos, Madrid, Espagne: Instituto Geologico y Minero de España.

Arthaud, F., and P. Matte, 1975, Les Décrochements Tardi-hercyniens du sud-ouest de l'Europe. Géométrie et essai de reconstitution des conditions de la déformation: Tectonophysics, v. 25, p. 139-171.

Augier, R., Jolivet, L., Robin, C., 2005. Late Orogenic doming in the eastern Betic Cordilleras: Final exhumation of the Nevado-Filabride complex and its relation to basin genesis. Tectonics 24, TC4003, doi:10.1029/2004TC001687

Avigad, D., and Z., Garkunkel, 1989, Low-angle faults above and below a blueschist beltTinos Island, Cyclades, Greece. Terra Nova, v. 1, no. 2, p. 182-187, doi:10.1111/j.1365-3121.1989.tb00350.x

Ballèvre M., V., Bosse, C., Ducassou, P., Pitra, 2009, Palaeozoic history of the Armorican Massif: Models for the tectonic evolution of the suture zones. Comptes Rendus Geoscience, 341, 174-201, doi:10.1016/j.crte.2008.11.009.

Barnard P, C., Thompson, S., Bastow, M. A., Ducreux. C., and G. Marthurin, 1992, Thermal maturity development and source-rock occurrence in the red sea and gulf of Aden. Journal of Petroleum Geology, vol 15, p. 173-186, doi: 10.1111/j.17475457.1992.tb00961.x.

Benvenuti, M., and I. P. Martini, 2002, Analysis of Terrestrial Hyperconcentrated Flows and their Deposit, in I. Peter Martini, V. R. Baker, and G. Garzn, eds., Flood and Megaflood Processes and Deposits: Oxford, UK, Blackwell Publishing Ltd., p. 167193, doi:10.1002/9781444304299.ch10.

Bixel, F., 1984, Le volcanisme stéphano-permien des Pyrénées. PhD thesis, University of Paul Sabatier, Toulouse, France, 638 p. 
Bixel, F., and C. L. Lucas, 1983, Magmatisme, tectonique et sédimentation dans les fossés stéphano-permiens des Pyrénées occidentales: Revue de géologie dynamique et de géographie physique, v. 24, no. 4, p. 329-342.

Bixel, F., and C. Lucas, 1987, Approche Géodynamique du Permien et du Trias des Pyrénées dans le cadre du sud-ouest européen: Cuadernos Geología Ibérica, v. 11, p. 57-81.

Blair, T. C., and J. G. McPherson, 1994, Alluvial fans and their natural distinction from rivers based on morphology, hydraulic processes, sedimentary processes, and facies assemblages: Journal of sedimentary research, v. 64, no. 3.

Boissonnas, J., G. Le Pochat, C. Thibault, and M. Bernatzk, 1974, Carte géologique de la France au 1/50000; feuille d'Iholdy, Orléans, France: Bureau de Recherche Géologique et minière.

Boone, S.C., Kohn, B.P., Gleadow, A.J.W., Morley, C.K., Seiler, C., Foster, D.A., Chung, L., 2018, Tectono-thermal evolution of a long-lived segment of the East African Rift System: Thermochronological insights from the North Lokichar Basin, Turkana, Kenya. Tectonophysics 744, p. 23-46, doi: 10.1016/j.tecto.2018.06.010.

Bridge, J. S., 1993, Description and interpretation of fluvial deposits: a critical perspective: Sedimentology, v. 40, no. 4, p. 801-810.

Bridge, J. S., 2009, Rivers and floodplains: forms, processes, and sedimentary record: John Wiley \& Sons.

Brun, J.-P., 1999. Narrow rifts versus wide rifts: inferences for the mechanics of rifting from laboratory experiments. Philos. Trans. R. Soc. Lond. A 357, 695-710.

Brun, J. -P, and J., Van Den Driessche, 1994, Extensional gneiss domes and detachement fault systems: structure and kinematics, BSGF, 165, 6, p. 519-530.

Brun, J.-P., D., Sokoutis, C., Tirel, F., Gueydan, J., Van Den Driessche, M.-O., Beslier, 2017, Crustal versus mantle core comSplexes, Tectonophysics, available online 28 Sept 2017, doi : 10.1016/j.tecto.2017.09.017 
Burg, J.-P., J. Van Den Driessche, and J.-P. Brun, 1994, Syn- to post-thickening extension : mode and consequences: Comptes rendus de l'Académie des sciences. Série 2. Sciences de la terre et des planètes, v. 319, no. 9, p. 1019-1032.

Canérot, J. C., 2016, The Iberian Plate: myth or reality?: Boletin Geologico y Minero, 127, p. 557-568.

Carreras J, Druguet E. 2014. Framing the tectonic regime of the NE Iberian Variscan segment. Geol. Soc. Spec. Publ. 405, 249-264. doi:10.1144/SP405.7

Cassinis, G., N. Toutin-Morin, and C. Virgili, 1995, A General Outline of the Permian Continental Basins in Southwestern Europe. In: Scholle P.A., Peryt T.M., UlmerScholle D.S. (eds) The Permian of Northern Pangea. Springer, Berlin, Heidelberg.

Casteras, M., 1971, Carte géologique de la France à 1/50 000: feuille de Tardets-Sorholus, Orléans, France: Bureau de Recherche Géologique et minière.

Chamyal, L. S., A. S. Khadkikar, J. N. Malik, and D. M. Maurya, 1997, Sedimentology of the Narmada alluvial fan, western India: Sedimentary Geology, v. 107, no. 3-4, p. $263-$ 279.

Chandrasekharam, D., Lashin, A., Al Arifi, N., Al-Bassam, A.M., Varun, C., 2018, Geochemical evolution of geothermal fluids around the western Red Sea and East African Rift geothermal provinces. J. Asian Earth Sci, 164, p. 292-306, doi: 10.1016/j.jseaes.2018.06.013.

Choukroune, P., 1976, Strain patterns in the Pyrenean chain: Philosophical Transactions of the Royal Society of London A: Mathematical, Physical and Engineering Sciences, v. 283 , no. 1312 , p. $271-280$.

Claude, D., 1990, Etude stratigraphique, sédimentologique et structurale des dépôts mésozoïques au nord du massif du Labourd: rôle de la faille de Pamplona (Pays Basque). PhD thesis, University of Bordeaux III, France, 437 p.

Cochelin, B., D. Chardon, Y. Denèle, C. Gumiaux, and B. Le Bayon, 2017, Vertical strain partitioning in hot Variscan crust: Syn-convergence escape of the Pyrenees in the 
Iberian-Armorican syntax: Bulletin de la Société Géologique de France, v. 188, no. 6, 39, doi:10.1051/bsgf/2017206

Cochelin, B., Lemirre, B., Denèle, Y., Blanquat, M. de S., Lahfid, A., Duchêne, S., 2018a, Structural inheritance in the central Pyrenees: the variscan to Alpine tectonometamorphic evolution of the axial zone. J. Geol. Soc., v. 175, 336-351, doi:10.1144/jgs2017-066.

Cochelin, B., Gumiaux, C., Chardon, D., Denèle, Y., Le Bayon, B., 2018b, Multi-scale strainfield analysis using geostatistics: Investigating the rheological behavior of the hot Variscan crust of the Pyrenees (Axial Zone). J. Struct. Geol., v. 116, 114-130, doi:10.1016/j.jsg.2018.07.024

Coney, P.J., 1980. Cordilleran metamorphic core complexes: an overview. In: Crittenden, M.D., Coney, P.J., Davis, G.H. (Eds.), Cordilleran Metamorphic Core Complexes. Geological Society of America Memoir, v. 153. pp. 7-34.

Curnelle, R., 1983, Evolution structuro-sédimentaire du Trias et de l'Infra-Lias d'Aquitaine: Bull. Cent. Rech. Explor. Prod. Elf-Aquitaine, v. 7, no. 1, p. 69-99.

Davis, G. A., G. S. Lister, and S. J. Reynolds, 1986, Structural evolution of the Whipple and South mountains shear zones, southwestern United States: Geology, v. 14, no. 1, p. 710, doi:10.1130/0091-7613(1986)14<7:SEOTWA>2.0.CO;2.

Davis, G. H., and P. J. Coney, 1979, Geologic development of the Cordilleran metamorphic core complexes: Geology, v. 7, no. 3, p. 120-124, doi:10.1130/00917613(1979)7<120:GDOTCM>2.0.CO;2.

Delaperrière E, de Saint Blanquat M, Brunel M, Lancelot J (1994) Géochronologie U Pb sur les zircons et monazites dans le massif du Saint Barthélémy. Bull Soc Géol Fr 2, 101112

Denèle, Y., Olivier, P., Gleizes, G., Barbey, P., 2007. The Hospitalet gneiss dome (Pyrenees) revisited: lateral flow during Variscan transpression in the middle crust, Terra Nova, v. 19, 445-453, doi:10.1111/j.1365-3121.2007.00770.x. 
Denèle, Y., Olivier, P., Gleizes, G., Barbey, P., 2009. Decoupling between the middle and upper crust during transpression-related lateral flow: variscan evolution of the Aston gneiss dome (Pyrenees, France), Tectonophysics, v. 477, 244-261, doi:10.1016/j.tecto.2009.04.033.

Denèle, Y., J.-L. Paquette, P. Olivier, and P. Barbey, 2012, Permian granites in the Pyrenees: the Aya pluton (Basque Country): Terra Nova, v. 24, no. 2, p. 105-113.

Denèle, Y., B. Laumonier, J.-L. Paquette, P. Olivier, G. Gleizes, and P. Barbey, 2014, Timing of granite emplacement, crustal flow and gneiss dome formation in the Variscan segment of the Pyrenees: Geological Society, London, Special Publications, v. 405, no. 1 , p. 265-287, doi: $10.1144 / \mathrm{SP} 405.5$

Domeier, M., Van der Voo, R., Torsvik, T.H., 2012. Paleomagnetism and Pangea: The road to reconciliation. Tectonophysics 514-517, p.14-43, doi:10.1016/j.tecto.2011.10.021

Ducasse, L., and P.-C. Velasque, 1988, Géotraverse dans la partie occidentale des Pyrénées, de l'avant-pays aquitain au bassin de l'Ebre: effet d'une inversion structurale sur l'édification d'une chaîne intracontinentale: Université Paul Cézanne (Aix-Marseille). Faculté des sciences et techniques de Saint-Jérôme, 287 p.

Ducoux, M., 2017, Structure, thermicité et évolution géodynamique de la Zone Interne Métamorphique des Pyrénées. PhD thesis, University of Orléans, France, 646 p.

Durand, M., 2006, The problem of the transition from the Permian to the Triassic Series in southeastern France: comparison with other Peritethyan regions: Geological Society, London, Special Publications, v. 265, no. 1, p. 281-296.

Echtler, H., and J. Malavieille, 1990, Extensional tectonics, basement uplift and StephanoPermian collapse basin in a late Variscan metamorphic core complex (Montagne Noire, Southern Massif Central): Tectonophysics, v. 177, no. 1-3, p. 125-138.

Faure, M., J.-M. Lardeaux, and P. Ledru, 2009, A review of the pre-Permian geology of the Variscan French Massif Central: Comptes Rendus Geoscience, v. 341, no. 2-3, p. 202-213. 
Franke, W., 1989, Variscan plate tectonics in Central Europe-current ideas and open questions: Tectonophysics, v. 169, no. 4, p. 221-228, doi:10.1016/00401951(89)90088-7.

Frizon de Lamotte, D., B. Fourdan, S. Leleu, F. Leparmentier, and P. de Clarens (2015), Style of rifting and the stages of Pangea breakup, Tectonics, 34, 1009-1029, doi:10.1002/2014TC003760.

Gaggero, L., Gretter, N., Langone, A., Ronchi, A., 2017. U-Pb geochronology and geochemistry of late Paleozoic in Sardinia (southern Variscides). Geosci. Front. 8, 1263-1284, doi:10.1016/j.gsf.2016.11.015.

Gisbert, J., 1981, Estudio geologico-petrologico del Estefaniense-Permico de la Sierra del cadi (Pireneo de Lérida): Diagenesis y sedimentologia, Thesis, Universitu of Zaragosa, Spain.

Gretter, N., Ronchi, A., López-Gómez, J., Arche, A., De la Horra, R., Barrenechea, J., Lago, M., 2015, The Late Palaeozoic-Early Mesozoic from the Catalan Pyrenees (Spain): $60 \mathrm{Myr}$ of environmental evolution in the frame of the western peri-Tethyan palaeogeography. Earth-Science Reviews, v. 150, 679-708, doi: 10.1016/j.earscirev.2015.09.001

Gueydan, F., Morency, C., Brun, J.-P., 2008, Continental rifting as a function of lithosphere mantle strength, Tectonophysics, v. 460, 83-93, doi:10.1016/j.tecto.2008.08.012.

Guitard G, Vielzeuf D, Martinez F. 1996. Métamorphisme hercynien. In Synthèse Géologique et Géophysique Des Pyrénées vol. 1. Orléans (France) : BRGM-ITGE, pp. 501-584.

Gutiérrez-Alonso G, Johnston ST, Weil AB, Pastor-Galán D, Fernández-Suárez J. 2012. Buckling an orogen: The Cantabrian Orocline. GSA Today 22: 4-9, doi: 10.1130/GSATG141A.1.

Hart, N. R., D. F. Stockli, and N. W. Hayman, 2016, Provenance evolution during progressive rifting and hyperextension using bedrock and detrital zircon $\mathrm{U}-\mathrm{Pb}$ geochronology, Mauléon Basin, western Pyrenees: Geosphere, v. 12, no. 4, p. 1166-1186, doi:10.1130/GES01273.1. 
Hart, N. R., D. F. Stockli, L. L. Lavier, and N. W. Hayman, 2017, Thermal evolution of a hyperextended rift basin, Mauléon Basin, western Pyrenees: Thermal evolution of hyperextended rift: Tectonics, doi:10.1002/2016TC004365.

Heddebaut, C., 1967, Observations tectoniques sur le massif des Aldudes (Basses-Pyrénées): CR Som. Soc. Géol. de France, fasc, v. 7, p. 280-281.

Heddebaut, C., 1973, Etudes géologiques dans les massifs paléozoïques basques. PhD thesis, University of Lille, France, 263 p.

Iverson, R. M., 1997, The physics of debris flows: Reviews of Geophysics, v. 35, no. 3, p. 245-296, doi:10.1029/97RG00426.

Izquierdo-Llavall, E., Casas-Sainz, A., M., Oliva-Urcia, B., 2013, Heterogeneous deformation recorded by magnetic fabrics in the Pyrenean Axial Zone. Journal of Structural Geology, v. 57, 97-113, doi:10.1016/j.jsg.2013. 10.005

Izquierdo-Llavall, E., Casas-Sainz, A., M., Oliva-Urcia, B., 2014, Heterogeneous deformation recorded by magnetic fabrics in the Palaeomagnetism and magnetic fabrics of the Late Palaeozoic volcanism in the Castejón-Laspaúles basin (Central Pyrenees). Implications for palaeoflow directions and basin configuration, Geological Magazine, v. 151, 777-797, doi: 10.1017/S0016756813000769

Jammes, S., G. Manatschal, L. Lavier, and E. Masini, 2009, Tectono-sedimentary evolution related to extreme crustal thinning ahead of a propagating ocean: Example of the western Pyrenees: Tectonics, v. 28, no. 4, doi:10.1029/2008TC002406.

Jolivet, L., and Goffé, B., 2000, Les dômes métamorphiques extensifs dans les chaînes de montagnes. Extension syn-orogénique et post-orogénique, Comptes Rendus Académie Sci. - Ser. IIA - Earth Planet. Sci, v. 330, p. 739-751, doi: 10.1016/S12518050(00)00220-2.

Jolivet, L., V. Famin, C. Mehl, T. Parra, C. Aubourg, R. Hébert, and P. Philippot, 2004, Strain localization during crustal-scale boudinage to form extensional metamorphic domes in the Aegean Sea: Special papers-Geological Society of America, p. 185-210. 
Jolivet, L., R. Augier, C. Faccenna, F. Negro, G. Rimmele, P. Agard, C. Robin, F. Rossetti, and A. Crespo-Blanc, 2008, Subduction, convergence and the mode of backarc extension in the Mediterranean region: Bulletin de la Société Géologique de France, v. 179 , no. 6 , p. 525-550.

Juch, D., H. F. Krausse, D. Muller, H. Requadt, D. Schafer, J. Sole, and L. Villalobos, 1972, Carte géologique de l'Espagne au 1/50000; feuille de Maya del Baztan, Madrid, Espagne: Instituto Geologico y Minero de España.

Lagabrielle, Y., P. Labaume, and M. de Saint Blanquat, 2010, Mantle exhumation, crustal denudation, and gravity tectonics during Cretaceous rifting in the Pyrenean realm (SW Europe): Insights from the geological setting of the lherzolite bodies: Tectonics, v. 29, no. 4, doi:10.1029/2009TC002588.

Lago, M., Arranz Yagüe, E., Pocoví, A., Galé Bornao, C., Gil-Imaz, A., 2004, Lower Permian magmatism of the Iberian Chain and its relationship to extensional tectonics. In: Wilson, M., Neumann, E.R., Davies, G., Timmermann, M., Heeremans, M., Larsen, B.T. (Eds.), Permo-Carboniferous Magmatism and Rifting in Europe. Special Publication, Geological Society of London, v. 223, pp. 465-491.

Lamare, P., 1931, Sur l'existence du Permien dans les Pyrénées basques, entre la Vallée de Baztan (Navarre espagnole) et la Vallée de Baïgorry (Basse Navarre française): CR Somm. Soc. Geol. Fr, v. 16, p. 242-245.

Lamare, P., 1939, La série paléozoïque du massif du Baygoura et de la vallée de la Nive; ses relations avec les terrains secondaires environnants: Bulletin de la Société Géologique de France, v. 9, p. 163-184.

Lamare, P., 1944, La terminaison orientale du massif des Aldudes, aux environs d'Arnéguy, révision de la feuille de Saint-Jean-Pied-de-Port au 1/80 000: Bulletin de la Carte Géologique de France, v. 45, no. 216, p. 265-305.

Laurent O., Couzinié S., Zeh A., Vanderhaeghe O., Moyen J.,-F., Villaros A., et al. 2017, Protracted, coeval crust and mantle melting during Variscan late-orogenic evolution: $\mathrm{U}-\mathrm{Pb}$ dating in the eastern French Massif Central. Int. J. Earth Sci., v. 106, 421-451. doi:10.1007/s00531-016-1434-9. 
Laverdière, J.-W., 1930, Les formations paléozoïques de la vallée du Laurhibar: Mém. Soc. Géol. Nord. Lille, v. 55, p. 156-157.

Le Pochat, G., C. Bolthenhagen, M. Lenguin, S. Lorsignol, and C. Thibault, 1976, Carte géologique de France au 1/50 000: Mauléon-licharre, Orléans, France.

Le Pochat, G., C. Heddebaut, M. Lenguin, S. Lorsignol, P. Souquet, J. Muller, and P. Roger, 1978, Carte Géologique de France au 1/50 000: St Jean Pied de Port, Orléans, France.

Le Pourhiet, L., B. Huet, D. A. May, L. Labrousse, and L. Jolivet, 2012, Kinematic interpretation of the 3D shapes of metamorphic core complexes: Geochemistry, Geophysics, Geosystems, v. 13, no. 9.

Le Roy, P., \& Piqué, A., 2001. Triassic-Liassic Western Moroccan synrift basins in relation to the Central Atlantic opening. Marine Geology 172, p. 359-381

Leleu, S., 2005, Les cônes alluviaux Crétacé supérieur/Paléocène en Provence: traceurs de l'évolution morpho-tectonique des stades précoces de collision. $\mathrm{PhD}$ thesis, University of Strasbourg 1, Strasbourg, France, 222 p.

Leleu, S., A. J. Hartley, C. van Oosterhout, L. Kennan, K. Ruckwied, and K. Gerdes, 2016, Structural, stratigraphic and sedimentological characterisation of a wide rift system: The Triassic rift system of the Central Atlantic Domain: Earth-Science Reviews, v. 158 , p. $89-124$.

Lemirre, B., 2018. Origine et développement de la thermicité dans les Pyrénées varisques. PhD thesis, Univ. Paul Sabatier, Toulouse, France, 299p.

Lemirre, B., Cochelin, B., Duchene, S., de Saint Blanquat, M., Poujol, M., 2019. Origin and duration of late orogenic magmatism in the foreland of the Variscan belt (Lesponne Chiroulet - Neouvielle area, french Pyrenees). Lithos 336-337, p. 183-201, doi: 10.1016/j.lithos.2019.03.037

Levson, V. M., and N. W. Rutter, 2000, Influence of bedrock geology on sedimentation in Pre-Late Wisconsinan alluvial fans in the Canadian Rocky Mountains: Quaternary International, v. 68-71, p. 133-146, doi:10.1016/S1040-6182(00)00039-2. 
Lister, G. S., and G. A. Davis, 1989, The origin of metamorphic core complexes and detachment faults formed during Tertiary continental extension in the northern Colorado River region, U.S.A.: Journal of Structural Geology, v. 11, no. 1, p. 65-94, doi:10.1016/0191-8141(89)90036-9.

Lister, G.S., Banga, G., and Feenstra, A., 1984, Metamorphic core complexes of cordilleran type in the Cyclades, Aegean Sea, Greece, Geology, v. 12, p. 221-225.

Lloret J., A., Ronchi, J., López-Gómez, N., Gretter, R., De la Horra, J., F., Barrenechea, A., Arche, 2018, Syn-tectonic sedimentary evolution of the continental late Palaeozoicearly Mesozoic Erill Castell-Estac Basin and its significance in the development of the central Pyrenees Basin, Sedimentary Geology, v. 374, 134-157, doi: 10.1016/j.sedgeo.2018.07.014

Lotout, C., Pitra, P., Poujol, M., Anczkiewick, R., Van Den Driessche, J., 2018, Timing and duration of Variscan high-pressure metamorphism in the French Massif Central: A multimethod geochronological study from the Najac Massif, Lithos, v. 308-309, 381394, doi: 10.1016/j.lithos.2018.03.022

Lucas, C., 1968, Le grès rouge du Comminges et de la Bigorre (Pyrénées centrales). PhD thesis, University of Paul Sabatier, Toulouse, France, 132 p.

Lucas, C., 1977, Le Trias des Pyrénées, corrélations stratigraphiques et paléogéographie: Bulletin du BRGM, v. 2, p. 225-231.

Lucas, C., 1985, Le grès rouge du versant nord des Pyrénées: essai sur la géodynamique de dépôts continentaux du permien et du trias, $\mathrm{PhD}$ Thesis ('thèse d'état'), University of Paul Sabatier, Toulouse, France, 267 p.

Lucas, C., J. Doubinger, and J. Broutin, 1980, Premières datations palynologiques dans les grès triasiques des Pyrénées: CR Acad. Sci., Paris, v. 291, p. 517-520.

Malavieille, J., 1993, Late orogenic extension in mountain belts: insights from the Basin and Range and the late Paleozoic Variscan belt: Tectonics, v. 12, no. 5, p. 1115-1130.

Malavieille, J., P. Guihot, S. Costa, J. M. Lardeaux, and V. Gardien, 1990, Collapse of the thickened Variscan crust in the French Massif Central: Mont Pilat extensional shear 
zone and St. Etienne Late Carboniferous basin: Tectonophysics, v. 177, no. 1-3, p. $139-149$.

Malod, J., A, 1982, Comparaison de l'évolution des marges continentales au nord et au sud de la péninsule ibérique. $\mathrm{PhD}$ thesis ('Thèse d'état'), University of Paris, France, 235 p.

Martínez-Catalán J.,R., Pascual F.,J.,R, Montes A.,D., Fernández R.,D., Barreiro J.,G., Silva Í,D.,D., et al. 2014, The late Variscan HT/LP metamorphic event in NW and Central Iberia: relationships to crustal thickening, extension, orocline development and crustal evolution, Geol Soc Spec Publ, v. 405, 225-247, doi: 10.1144/SP405.1.

Masini, E., G. Manatschal, J. Tugend, G. Mohn, and J.-M. Flament, 2014, The tectonosedimentary evolution of a hyper-extended rift basin: the example of the ArzacqMauléon rift system (Western Pyrenees, SW France): International Journal of Earth Sciences, v. 103, no. 6, p. 1569-1596, doi:10.1007/s00531-014-1023-8.

Matte, P., 2001, The Variscan collage and orogeny (480-290 Ma) and the tectonic definition of the Armorica microplate: a review: Terra nova, v. 13, no. 2, p. 122-128.

Matte, P., and A. Hirn, 1988, Seismic signature and tectonic cross section of the Variscan crust in western France: Tectonics, v. 7, no. 2, p. 141-155.

McKenzie, D., 1978, Some remarks on the development of sedimentary basins: Earth and Planetary Science Letters, v. 40, no. 1, p. 25-32, doi:10.1016/0012-821X(78)90071-7.

Merle, J.-M., 1974, Recherches sur les relations paléogéographiques et structurales entre les massifs basques au sud de Saint-Jean-Pied-de-Port (Pyrénées occidentales). PhD thesis, University of Paul Sabatier, Toulouse, France, 142 p.

Mey, P. H. W., Nagtegaal, P. J. C., Roberti, K. J. and J. J. A. Hartevelt, 1968, Lithostratigraphic subdivision of post-Hercynian deposits in South-Central Pyrenees, Spain, Leidse. Geol. Meded, v. 41, p. 221-228.

Miall, A. D., 1977a, A review of the braided-river depositional environment: Earth-Science Reviews, v. 13, no. 1, p. 1-62.

Miall, A. D., 1977b, Lithofacies types and vertical profile models in braided river deposits: a summary: Geological Survey of Canada, p. 597-604. 
Muller, J., and P. Roger, 1977, L'Evolution structurale des Pyrénées (Domaine central et occidental) Le segment hercynien, la chaîne de fond alpine: Géologie alpine, v. 53, no. 2, p. 149-191.

Muttoni, G., Gaetani, M., Kent, D.V., Sciunnach, D., Angiolini, L., Berra, F., Garzanti, E., Mattei, M., Zanchi, A., 2009. Opening of the Neo-Tethys Ocean and the Pangea B to Pangea A transformation during the Permian. GeoArabia 14 (4), p 17-48.

Nagtegaal, P, J, G, 1969, Sedimentology, paleoclimatology and diagenesis of post-Hercynian deposits in South-Central Pyrenees, Spain, Leidse. Geol. Meded, v. 42, p. 143-288.

Olivet, J. L., 1996, La cinématique de la plaque ibérique: Bull. Cent. Rech. Explor. Prod. Elf Aquitaine, v. 20, no. 1, p. 131-195.

Olivier, Ph., Gleizes, G., and Paquette, J.L., 2004, Gneiss domes and granite emplacement in an obliquely convergent regime: New interpretation of the Variscan Agly Massif (Eastern Pyrenees, France), in Whitney, D.L., Teyssier, C., and Siddoway, C.S., eds., Gneiss domes in orogeny: Geological Society of America Special Paper 380, p. 229242.

Omenda, P.A., 1997. The geology and structural controls of the Olkaria goethermal system, Kenya. Geothermics 27, 1, pp 55-74

Orejana, D., Villaseca, C., Billström, K., Paterson, B. A., 2008, Petrogenesis of Permian alkaline lamprophyres and diabases from the Spanish Central System and their geodynamic context within western Europe, Contrib. Mineral. Petrol. 156, p. 477-500, doi:10.1007/s00410-008-0297-x

Paquette, J.-L., Ballèvre, M., Peucat, J.-J., Cornen, G., 2017, From opening to subduction of an oceanic domain constrained by LA-ICP-MS U-Pb zircon dating (Variscan belt, Southern Armorican Massif, France), Lithos, v. 294-295, 418-437, doi: 10.1016/j.lithos.2017.10.005

Pellenard, P., Gand, G., Schmitz, M., Galtier, J., Broutin, J., Stéyer, J-S., 2017, Highprecision U-Pb zircon ages for explosive volcanism calibrating the NW European continental Autunian stratotype, Gondwana Research, v. 51, 118-136 doi: 10.1016/j.gr.2017.07.014 
Pereira, M.F., Castro, A., Chichorro, M., Fernández, C., Díaz-Alvarado, J., Martí, J., Rodríguez, C., 2014, Chronological link between deep-seated processes in magma chambers and eruptions: Permo-Carboniferous magmatism in the core of Pangaea (Southern Pyrenees), Gondwana Res., v. 25, 290-308, doi: 10.1016/j.gr.2013.03.009

Pierson, T. C., and K. M. Scott, 1985, Downstream Dilution of a Lahar: Transition From Debris Flow to Hyperconcentrated Streamflow: Water Resources Research, v. 21, no. 10, p. 1511-1524, doi:10.1029/WR021i010p01511.

Pin, C., Vielzeuf, D., 1983. Granulites and related rocks in variscan median Europe: a dualistic interpretation. Tectonophysics 93, 47-74.

Pochat, S., and J., Van Den Driessche, 2011, Filling sequence in Late Paleozoic continental basins: A chimera of climate change? A new light shed given by the GraissessacLodève basin (SE France), Palaeogeogr. Palaeoclimatol. Palaeoecol, v. 302, p. 170186, doi: 10.1016/j.palaeo.2011.01.006.

Pohl F., N., Froitzheim, G., Obermüller, F., Tomaschek, O., Schröder, T. J., Nagel, D., Sciunnach, and A., Heuser, 2018, Kinematics and Age of Syn-Intrusive Detachment Faulting in the Southern Alps: Evidence for Early Permian Crustal Extension and Implications for the Pangea A Versus B Controversy, Tectonics, first published 04 October 2018, doi: 10.1029/2018TC004974

Poitrenaud T, Poujol M, Augier R, Marcoux E (In Press) The polyphase evolution of a lateVariscan W/Au deposit (Salau, French Pyrenees): Insights from REE and U/Pb LAICP-MS analyses. Mineralium Deposita.

Puigdefàbregas, C., and P. Souquet, 1986, Tecto-sedimentary cycles and depositional sequences of the Mesozoic and Tertiary from the Pyrenees: Tectonophysics, v. 129, no. $1-4$, p. 173-203.

Quintana, L., J. A. Pulgar, and J. L. Alonso, 2015, Displacement transfer from borders to interior of a plate: A crustal transect of Iberia: Tectonophysics, v. 663, p. 378-398, doi:10.1016/j.tecto.2015.08.046. 
Ranalli, G., and L., Rybach, 2005, Heat flow, heat transfer and lithosphere rheology in geothermal areas: Features and examples, J. Volcanol. Geotherm. Res, v. 148, p. 3-19, doi: 10.1016/j.jvolgeores.2005.04.010.

Rat, P. et al., 1983, Vue sur le Cretacé basco-cantabrique et nord-ibérique: Une marge et son arriere-pays, ses environnements sedimentaires: Memoires geologiques Universite de Dijon, v. 9, p. 191.

Razin, P., 1989, Evolution tecto-sédimentaire alpine des Pyrénées basques à l'ouest de la transformante de Pamplona, Province du Labourd. PhD thesis, University of Bordeaux 3, France, 464 p.

Ren, J., Tamaki, K., Li, S., and Z., Junxia, 2002. Late Mesozoic and Cenozoic rifting and its dynamic setting in Eastern China and adjacent areas, Tectonophysics, v. 344, p. 175205, doi: 10.1016/S0040-1951(01)00271-2.

Richard, P., 1986, Structure et évolution alpine des massifs paléozoïques du Labourd (Pays Basque français): Éditions du Bureau de recherches géologiques et minières, 374 p.

Rodríguez-Méndez L., J. Cuevas, J.J., Esteban, J. M., Tubía, S., Sergeev and A., Larionov, 2014, Age of the magmatism related to the inverted Stephanian-Permian basin of the Sallent area (Pyrenees), Geological Society, London, Special Publications 2014, v.394, doi: 10.1144/SP394.2

Roger, F., C. Teyssier, J.-P. Respaut, P. F. Rey, M. Jolivet, D. L. Whitney, J.-L. Paquette, and M. Brunel, 2015, Timing of formation and exhumation of the Montagne Noire double dome, French Massif Central: Tectonophysics, v. 640, p. 53-69.

Rosenbaum, G., G. S. Lister, and C. Duboz, 2002, Relative motions of Africa, Iberia and Europe during Alpine orogeny: Tectonophysics, v. 359, no. 1-2, p. 117-129, doi:10.1016/S0040-1951(02)00442-0.

Rossi, P., A. Cocherie, C. M. Fanning, and Y. Ternet, 2003, Datation U-Pb sur zircons des dolérites tholéiitiques pyrénéennes (ophites) à la limite Trias-Jurassique et relations avec les tufs volcaniques dits «infra-liasiques» nord-pyrénéens: Comptes Rendus Geoscience, v. 335, no. 15, p. 1071-1080, doi:10.1016/j.crte.2003.09.011. 
Rossi, P., Cocherie, A., Fanning, C.M., 2015. Evidence in Variscan Corsica of a brief and voluminous Late Carboniferous to Early Permian volcanic-plutonic event contemporaneous with a high temperature/low-pressure metamorphic peak in the lower crust. Bull, Soc. géol. France, v. 186, p. 171-192.

Rust, B. R., 1978, Depositional models for braided alluvium, in Fluvial Sedimentology: Miall, Mem. Can. Soc. Pet. Geol, p. 605-625.

de Saint-Blanquat M., 1993. La faille normale du massif du Saint Barthélémy. Évolution hercynienne des massifs nord-pyrénéens catazonaux considérée du point de vue de leur histoire thermique. Geodin Acta 6: 59-77.

de Saint Blanquat, M., Lardeaux, J.M., Brunel, M., 1990, Petrological arguments for high temperature extensional deformation in the Pyrenean Variscan crust (Saint Barthélémy Massif, Ariège, France).Tectonophysics 177, 245-262.

Saspiturry, N., Razin, P., Baudin, T., Serrano, O., Issautier, B., Lasseur, E., Allanic, C., Thinon, I., and Leleu, S., 2019, Symmetry vs. Asymmetry of a hyper-thinned rift basin: example of the Mauléon Basin (Western Pyrenees, France): Marine and Petroleum Geology, v. 104, p. 86-105, doi: 10.1016/j.marpetgeo.2019.03.031.

Saura, A., and A., Teixell, 2006, Inversion of small basins: effects on structural variations at the leading edge of the Axial Zone antiformal stack (Southern Pyrenees, Spain), Journal of Structural Geology, v. 28, 1909-1920, doi: 10.1016/j.jsg.2006.06.005

Schoeffler, J., 1965, Une hypothèse sur la tectonique de la chaîne pyrénéenne et de ses abords. Bull. Soc.Géol. Fr., 7, 6, p 917-920.

Schoeffler, J., 1982, Les transversales basco-landaises. Bull. Centre de Rech. Explor.-Prod. Elf-Aquitaine, 6.1, 257-263.

Schott. J. J., 1985, Paléomagnétisme des séries rouges du Permien, du Trias et du Crétacé 919 inférieur dans les chaînes pyrénéo-cantabrique et nord-ouest ibérique, implications 920 géodynamiques. PhD thesis, University of Strasbourg, France.

Sengör, A.M.C., Yilmaz, Y., Songurlu, O., 1984. Tectonics of the Mediterranean Cimmerides: nature and evolution of the western termination of Palaeo-Tethys. In: 
Dixon, I.E., Robertson, A.F. (Eds.), The Geological Evolution of the Eastern Mediterranean. Special Publication, Geological Society of London 17, pp. 77-112.

Sibuet, J.-C., S. P. Srivastava, and W. Spakman, 2004, Pyrenean orogeny and plate kinematics: Journal of Geophysical Research: Solid Earth, v. 109, no. B8, p. B08104, doi:10.1029/2003JB002514.

Souquet, P., B. Peybènes, M. Bilotte, and E.-J. Debroas, 1977, La chaîne alpine des Pyrénées: Géologie alpine, v. 53, no. 2, p. 193-216.

Stampfli, G.M., 1996, Intra-Alpine terrane: a Palaeotethyan remnant in the Alpine Variscides, Eclogea Geol Helv, v. 89, p. 13-42.

Stampfli, G.M., 2012, The geodynamics of Pangea formation. Géologie de la France, 208210.

Teixell, A., 1998, Crustal structure and orogenic material budget in the west central Pyrenees, Tectonics, v. 17, no. 3, 395-406, doi: 10.1029/98TC00561

Teixell, A., P. Labaume, and Y. Lagabrielle, 2016, The crustal evolution of the west-central Pyrenees revisited: Inferences from a new kinematic scenario: Comptes Rendus Geoscience, v. 348, no. 3-4, p. 257-267, doi:10.1016/j.crte.2015.10.010.

Tirel, C., 2004, Dynamique de l'extension des domaines continentaux épaissis: dômes métamorphiques et écoulement de la croûte ductile. PhD thesis, University of Rennes 1, France.

Tirel, C., J.-P. Brun, and E. Burov, 2004, Thermomechanical modeling of extensional gneiss domes: Geological Society of America Special Papers, v. 380, p. 67-78, doi:10.1130/0-8137-2380-9.67.

Tirel, C., Brun, J.-P., Burov, E., 2008, Dynamics and structural development of metamorphic core complexes. J. Geophys. Res., v. 113, B04403, doi:10.1029/2005JB003694.

Tugend, J., G. Manatschal, N. J. Kusznir, E. Masini, G. Mohn, and I. Thinon, 2014, Formation and deformation of hyperextended rift systems: Insights from rift domain mapping in the Bay of Biscay-Pyrenees: Tectonics, v. 33, no. 7, p. 1239-1276, doi:10.1002/2014TC003529. 
Vacherat, A., F. Mouthereau, R. Pik, D. Huyghe, J.-L. Paquette, F. Christophoul, N. Loget, and B. Tibari, 2017, Rift-to-collision sediment routing in the Pyrenees: A synthesis from sedimentological, geochronological and kinematic constraints: Earth-Science Reviews, v. 172, p. 43-74.

Vai, G, B., 2003, Development of the paleogeography of Pangea from Late Carboniferous to Early Permian, Palaeogeogr. Paleoclimatol. Palaeoecol, v. 196, p. 125-155.

Vielzeuf, D., 1984, Relations de phases dans le faciès granulite et implications géodynamiques: l'exemple des granulites des Pyrénées. $\mathrm{PhD}$ thesis, University of Clermont-Ferrand II, France.

Viennot, P., and Y. Kieh, 1928, Observations pétrographiques dans le massif cristallin du Labourd (Basses Pyrénées): Bull. Soc. Géol. Fr, v. 28, p. 369-379.

Viseras, C., M. L. Calvache, J. M. Soria, and J. Fernández, 2003, Differential features of alluvial fans controlled by tectonic or eustatic accommodation space. Examples from the Betic Cordillera, Spain: Geomorphology, v. 50, no. 1-3, p. 181-202.

Wang, Y. et al., 2016, The deep roots of the western Pyrenees revealed by full waveform inversion of teleseismic P waves: Geology, v. 44, no. 6, p. 475-478, doi:10.1130/G37812.1.

Weil A, Gutiérrez-alonso G, Conan J. 2010. New time constraints on lithospheric-scale oroclinal bending of the Ibero-Armorican Arc: a palaeomagnetic study of earliest Permian rocks from Iberia. J. Geol. Soc. 167: 127-143, doi: 10.1144/0016-76492009002.

Wernicke, B., 1981, Low-angle normal faults in the Basin and Range Province: nappe tectonics in an extending orogen: Nature, v. 291, no. 5817, p. 645-648, doi:10.1038/291645a0.

Wernicke, B., 1985, Uniform-sense normal simple shear of the continental lithosphere: Canadian Journal of Earth Sciences, v. 22, no. 1, p. 108-125, doi:10.1139/e85-009.

Wernicke, B., and B. C. Burchfiel, 1982, Modes of extensional tectonics: Journal of Structural Geology, v. 4, no. 2, p. 105-115, doi:10.1016/0191-8141(82)90021-9. 
Ziegler, P.A., 1990, Permo-Triassic development of Pangaea. In: Ziegler, P.A. (Ed.)Geological Atlas of Western and Central Europe. Shell International Petroleum Maatsschappij B.V. and Geological Society of London, p. 68-90.

Ziegler, P.A., Stampfli, G.M., 2001, Late Palaeozoic-Early Mesozoic plate boundary reorganization: collapse of the Variscan orogen and opening of Neotethys. Natura Bresciana. Annali del Museo Civico di Scienze Naturali di Brescia 25, p. 17-34. 


\section{Highlights}

- The N-S Bidarray basin is filled by E-W alluvial fans interdigitating with an N-S fluvial system.

- The Permian basin formation and the exhumation of granulites are coeval, induced by a single E-W extensional phase.

- The Ursuya gneiss dome is interpreted as an "a-type" metamorphic core complex.

- Preservation of the Permian-Triassic paleogeographic and structural templates despite Cretaceous hyper-extension and Tertiary inversion.

- The Mesozoic strike-slip motion of Iberian plate may have been distributed within the Cretaceous rift system or may have affected a more southern area. 